\title{
Organic matter breakdown and ecosystem metabolism: functional indicators for assessing river ecosystem health
}

\author{
Roger G. Young ${ }^{1}$ \\ Cawthron Institute, Private Bag 2, Nelson, New Zealand
}

\author{
Christoph D. Matthaei ${ }^{2}$ AND Colin R. Townsend ${ }^{3}$ \\ Department of Zoology, University of Otago, P.O. Box 56, Dunedin, New Zealand
}

\begin{abstract}
River health monitoring traditionally has made use of structural measurements (water quality or taxonomic composition of aquatic organisms). We argue that a more complete assessment of river health should include functional metrics, such as rates of organic matter decomposition and ecosystem metabolism. Leaf breakdown links the characteristics of riparian vegetation with the activity of both aquatic invertebrates and microbial organisms and is affected by natural and human-induced variation in a wide range of environmental factors. Measurement of leaf breakdown is relatively simple and has modest equipment requirements. River metabolism (gross primary productivity and ecosystem respiration) measures the rates of production and use of organic $C$ in river ecosystems as a whole, providing a direct estimate of the food base that determines life-supporting capacity. Metabolism measurements require more sophisticated equipment than do measurements of leaf breakdown, but improvements in technology have made metabolism measurements relatively easy. We review the factors that influence leaf breakdown and river metabolism and pay particular attention to the effects of human-induced environmental stressors. We also describe how measurements can be standardized and suggest criteria for interpreting functional measures in terms of river ecosystem health. Last, we consider the strengths and weaknesses of both methods as functional measures and provide recommendations for their use as biomonitoring tools.
\end{abstract}

Key words: river health, ecosystem function, organic matter decomposition, leaf litter, ecosystem metabolism, respiration, gross primary production, ecological integrity, environmental monitoring.

The state of a river can vary along a gradient of impairment from pristine to severely impacted. A critical part of improving the state of rivers is the ability to assess their ecological state accurately, so that the causes of degradation or the success of rehabilitation efforts can be measured. Resource managers can use 1 or more measures of condition to assess or monitor river health. River health traditionally has been assessed with structural measures related to physicochemistry or community composition (macroinvertebrates, algae, or microbes) (Barbour et al. 1999, Boulton 1999). However, river ecosystems also have functional components (Meyer 1997), which include rates, patterns, and relative importance of ecosystem processes. Adequate characterization of ecosystems

\footnotetext{
${ }^{1}$ E-mail addresses: roger.young@cawthron.org.nz

2 christoph.matthaei@stonebow.otago.ac.nz

3 colin.townsend@stonebow.otago.ac.nz
}

requires information on both structure and function (Gessner and Chauvet 2002) because stressors might cause changes to structure but not function, to function but not structure, or to both (e.g., Matthews et al. 1982, Bunn and Davies 2000, Riipinen et al. 2008). Direct measurements of ecosystem function also might enable better discrimination among classes along a gradient of biological condition (Davies and Jackson 2006).

The only functional metric that is used routinely in water-quality assessment is biochemical $\mathrm{O}_{2}$ demand (BOD), which is a measure of the total potential respiration within the water column and is most suited to sites influenced by wastewater discharges. Other ecosystem processes potentially could be used as functional indicators of river ecosystem health. These processes include rates of nutrient uptake (Sabater et al. 2000), microbial respiration (Hill et al. 2002), nitrification (Bernhardt et al. 2002), fine particulate organic matter export (Wallace et al. 1996), coarse 
particulate organic matter retention (Quinn et al. 2007), and invertebrate production (Buffagni and Comin 2000). However, some of these measures involve large effort or sophisticated and expensive equipment. Rates of leaf breakdown (Young et al. 1994, Benfield 1996, Gessner and Chauvet 2002) and ecosystem metabolism (the combination of algal productivity and ecosystem respiration; Hornberger et al. 1977, Bott 1996, Hill et al. 1997, Young and Huryn 1999, Bunn and Davies 2000, Fellows et al. 2006) are sensitive to environmental stressors and are relatively inexpensive and easy to measure. Leaf breakdown is an integrative process that links riparian vegetation and microbial and invertebrate activities. River metabolism measures the rates of production and use of organic $\mathrm{C}$ and, thus, provides a direct estimate of the food base and the way energy moves through the river food web. Both factors respond to many physical and chemical stressors (Mulholland et al. 2001, Pascoal et al. 2003).

An ideal indicator would respond predictably to anthropogenic stressors but be relatively insensitive to natural spatial or temporal variation (Norris and Hawkins 2000). This ideal is difficult to achieve because sensitive indicators, such as leaf breakdown and metabolism, respond to natural variation and to human-induced changes to ecosystems. Tradeoffs among generality, sensitivity, and robustness are inevitable when choices must be made among appropriate indicators (Gessner and Chauvet 2002). If possible, indicators of ecosystem health should be set against a local baseline of (more or less) pristine sites that have natural physicochemical characteristics equivalent to what would be expected in the (potentially) impaired sites under study. Good indicators should be economical to measure, provide easily interpreted outputs, relate to appropriate scales and management goals, and be scientifically defensible (Norris and Hawkins 2000).

We discuss natural variation in rates of leaf breakdown and river metabolism in relation to instream physicochemistry and geographic and landscape features and pay particular attention to the influence of a wide variety of human effects. We consider advantages and disadvantages of alternative measurement protocols for each indicator and provide a framework for distinguishing between healthy and unhealthy systems.

\section{Leaf Decomposition}

\section{Review of factors controlling leaf decomposition}

The many factors that control leaf decomposition range from those that vary naturally from site to site (e.g., climate, longitudinal position in the river) to those that are strongly influenced by anthropogenic disturbance to ecosystems (e.g., toxic chemicals, organic pollution). Most of these factors vary as a result of both natural and anthropogenic causes (e.g., nutrients, $\mathrm{pH}$, sediment, riparian vegetation, temperature). The role of terrestrial leaf litter as an energy source to stream ecosystems has been widely studied since the 1970s (Table 1).

Leaf decomposition responds systematically to certain natural features of a river, and these responses must be taken into account when using leaf decomposition as a measure of ecosystem health. For example, leaf breakdown usually is faster in warm than in cold water (Table 1). Therefore, breakdown rates often differ between rivers with different altitudes or climates or that are in different ecoregions. Rivers at different altitudes or in different ecoregions also show systematic variation in naturally occurring nutrient concentrations, hydrological regimes, river geomorphology and bed substrate, and the nature of the riparian vegetation (which influences stream temperature via shading). Even in identical physicochemical settings, particular species that have strong effects in the food web might have far-reaching effects on leaf decomposition. Within a given river, leaves generally decompose faster at sites where leaf-eating invertebrates are more abundant. Distributions of leaf-eating insects, crayfish, or fish that prey upon the leaf eaters are patchy at a range of scales, and species might be present or absent at the catchment scale, in individual tributaries, or even in reaches within a tributary. Unexpected variation in breakdown rates might be caused by patchy distributions of particularly influential consumers (Table 1). The influence of those natural features that might affect the process of leaf decomposition must be removed from assessments of the influence of anthropogenic activities, such as input of fine sediment, organic matter, plant nutrients, and toxic chemicals, and changes to $\mathrm{pH}$, temperature, and hydrology.

Human activities in a catchment often are reflected by changes in $>1$ stressor (Table 1 ). For example, when riparian vegetation is removed for agricultural or urban development, temperature, nutrient concentrations, and fine sediment input into the stream all are likely to increase. Multiple stressors might operate in concert to increase leaf breakdown rates, as would be the case when temperature and nutrient concentrations are increased simultaneously. On the other hand, positive effects of higher nutrient concentrations have counteracted negative effects of more fine sediment in streams in catchments developed for grazing (Niyogi et al. 2003). Similarly, the negative effects of increased heavy metal concentrations have counteracted the positive effects of high nutrient concentrations (Sridhar 
et al. 2001). Pascoal et al. (2001) also reported that declines in leaf processing by invertebrates, caused by inputs of treated sewage effluent, were more than compensated by increased microbial activity.

\section{Measurement of leaf breakdown}

Leaf breakdown is measured by securing bunches of preweighed leaves to the streambed (as leaf packs or in mesh bags) and retrieving them after a certain period. Enclosing the leaves in mesh bags standardizes the approach and reduces abrasion-induced mass losses of large leaf fragments that have not been totally decomposed (Meyer 1980, Boulton and Boon 1991). On the other hand, leaf decay might be underestimated in mesh bags because of size-selective exclusion of some or all macroinvertebrates, the potential for anoxic conditions to develop in the center of the bag (Boulton and Boon 1991), and the tendency for fine sediment to accumulate within the bag (Dangles et al. 2001). However, these problems can be circumvented by using appropriate mesh sizes and relatively small leaf bags and by exposing leaf bags for relatively short periods of time (Boulton and Boon 1991). Coarse-mesh bags (0.5-1-cm aperture) allow colonization by leafeating macroinvertebrates, and, thus, conditions in coarse-mesh bags simulate natural leaf breakdown more closely than do conditions in fine-mesh bags (e.g., Chergui and Pattee 1988, Stewart and Davies 1989, Gonzalez et al. 1998, Gessner and Chauvet 2002, Menendez et al. 2003). Both coarse- and fine-mesh bags $(\leq 1 \mathrm{~mm}$ ) should be used (e.g., Gonzalez et al. 1998, Menendez et al. 2003, Pascoal et al. 2003), if feasible, to permit assessment of the relative contributions of macroinvertebrates and microorganisms (fungi and bacteria) to leaf breakdown (Gessner and Chauvet 2002).

Many studies have provided information on relative decay rates of leaf species in different parts of the world (e.g., Bärlocher et al. 1995, Quinn et al. 2000, Haapala et al. 2001, Sampaio et al. 2001, Hieber and Gessner 2002, Pascoal et al. 2003). Most researchers have emphasized realism in leaf breakdown studies by selecting leaves from the riparian zone (Boulton and Boon 1991). However, when leaf breakdown is used as a functional measure of river health, relative measures (i.e., comparisons between polluted and unpolluted reference sites) are often more important than absolute breakdown rates, and leaf type and treatment should be standardized among sites. A species that decays relatively fast has the advantage of a possibly shorter exposure period. On the other hand, a more slowly decomposing species could be selected if retrieval might be delayed for logistic reasons. Use of freshly fallen leaves allows assessment of the natural decomposition process (Boulton and Boon 1991), but logistic constraints are likely to preclude this approach if comparable studies are to be carried out in many locations. To minimize variability, leaves should be picked from trees at a single location and air-dried prior to exposure in leaf bags (Boulton and Boon 1991).

A promising alternative technique is the cellulose decomposition potential method (Hildrew et al. 1984, Boulton and Quinn 2000, Tiegs et al. 2007), which was first used in streams by Egglishaw (1972). Strips of standard cotton cloth are deployed in the stream, and the extent of cellulose decomposition is measured as loss in tensile strength. Other standard substrates, such as wooden sticks, also have potential (Tank and Winterbourn 1996, McTammany et al. 2008). Use of standard substrates ensures that comparisons of decay rates among sites are not confounded by variability in the chemical composition of the initial substrate (Tiegs et al. 2007). Standard substrates are relatively inexpensive and are less prone to fragmentation and are easier to transport than leaves (Egglishaw 1972, Tiegs et al. 2007).

In most studies, replicate leaf packs or bags are retrieved after various periods of exposure (e.g., Hill et al. 1992, Gonzalez et al. 1998, Haapala et al. 2001, Hieber and Gessner 2002, Menendez et al. 2003), but a single retrieval period (e.g., $1 \mathrm{mo}$ ) might be adequate if effort must be minimized. Decomposition rates vary with time of year, and the most realistic values will be obtained at the time of peak leaffall (Garden and Davies 1988, Boulton and Boon 1991, Lopez et al. 2001, Menendez et al. 2003, Pascoal et al. 2003). Complete decay of leaves reduces power to detect differences among sites. Thus, the ideal period of deployment is one that results in $\sim 50 \%$ loss of mass or strength. This period provides sufficient time for detection of differences among sites but insufficient time for complete leaf decay at most sites.

Leaf bags should be securely fastened to metal pegs ( $\geq 15-20 \mathrm{~cm}$ long) anchored to the stream bottom and driven beneath the bed surface so that hydraulic conditions are not dramatically altered. Bags should not be allowed to float in the water column because of potential effects on decay rates (Mutch et al. 1983). Leaf bags should be tethered in areas where leaves are likely to accumulate naturally to mimic the natural rate of leaf decomposition (Boulton and Boon 1991). Breakdown rates differ among habitat types within streams. Leaves buried in debris dams and pools typically decompose slowly, whereas leaves in riffles decompose faster (Meyer 1980, Casas 1996). Measures of ecosystem health rely on comparisons among sites, so the habitat types in which leaves are positioned 
TABLE 1. Expected patterns in leaf breakdown in relation to natural variation and responses to environmental stressors.

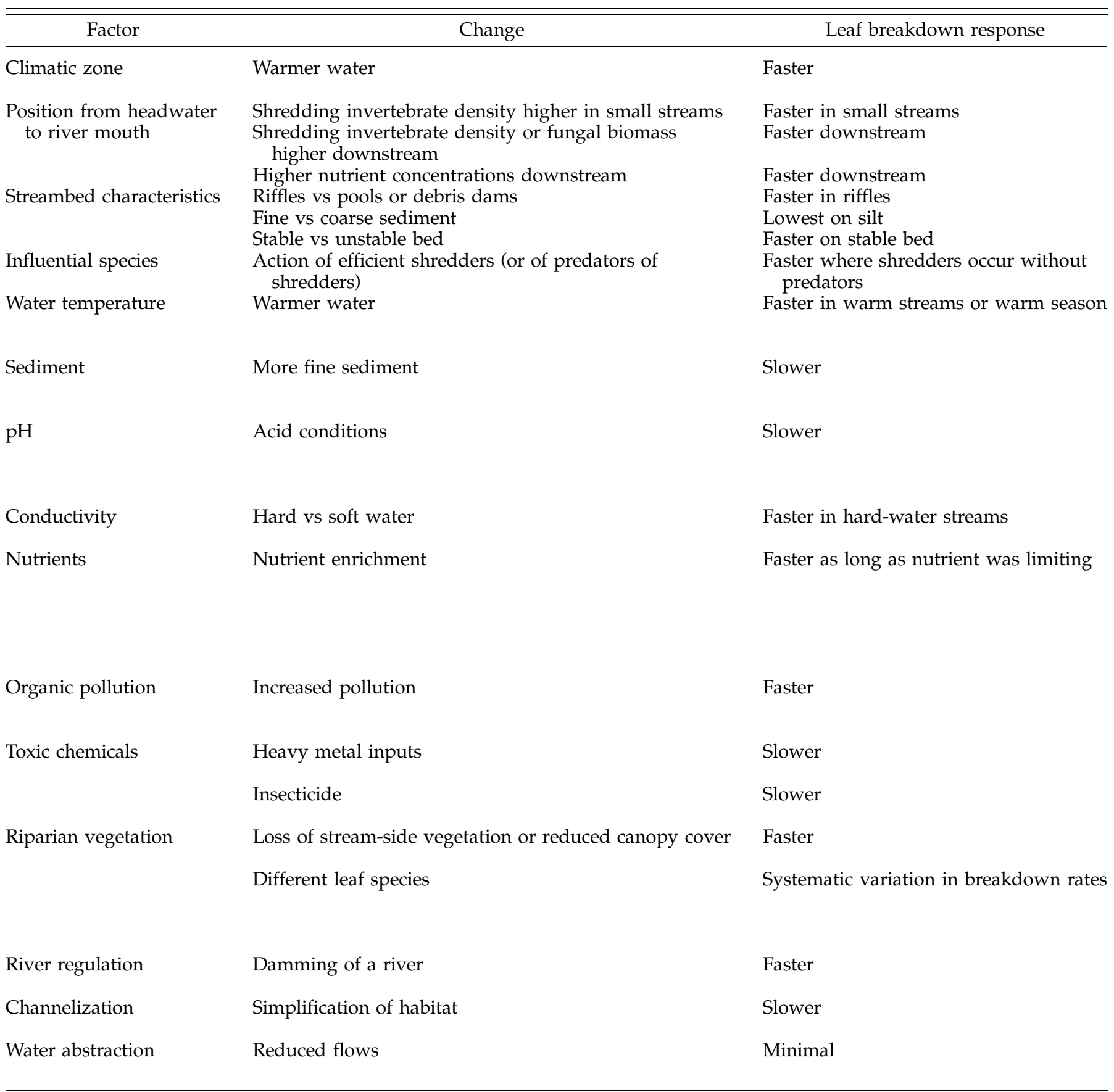

should be as consistent as possible among sites. We recommend that riffles be used as a standard habitat type because leaves naturally accumulate (Speaker et al. 1984), invertebrate density and diversity are often high (Brown and Brussock 1991), and sediment deposition and leaf pack burial are less likely in riffles than in other habitats. In larger rivers, riffles also are the shallowest areas, so leaf bag deployment and recovery often are easier in riffles.
The simplest way to assess leaf breakdown is to measure mass loss (as ash-free dry mass to circumvent the problem of inorganic sediment accumulation) of leaves during the period of deployment. One of the problems associated with mass-loss measurements is that some of the measured loss might result from loss of large leaf fragments through physical abrasion rather than biological or chemical decomposition. An alternative measure that could be used on remaining 
TABLE 1. Extended.

Comments References

See "Water temperature" below

Depends on rate of invertebrate shredding

See "Nutrients" below

Invertebrate density or leaf abrasion higher in riffles Invertebrate densities lower or anaerobic

Higher invertebrate density

Crayfish very important, but fish might reduce shredder activity

Microorganisms most responsive to temperature; if invertebrate density is high in cold season, leaf decay is faster

Lower invertebrate density or anaerobic conditions

Reduced invertebrate or microorganism activity

Shredding invertebrate density or microorganism activity increases with conductivity

Response might be counteracted by increased sediment

Response to nutrient stimulation but might be counteracted by changes to invertebrate community

Via reduced invertebrate and microbial activity

Via reduced invertebrate density (experiment with herbicide had no effect)

Via warmer water temperatures, but counteracted by increased sedimentation soon after logging

Depends on leaf chemistry (nutrients and toxins) and fiber content

Warmer temperatures in winter, but depends on nature of invertebrate community

Via loss of natural leaf accumulations and leaf-eating invertebrates

Probably depends on magnitude of flow reduction and effect on other factors
Gessner et al. 1998, Robinson et al. 1998, Mathuriau and

Chauvet 2002, but see Chergui and Pattee 1991

Baldy et al. 1995, Jonsson et al. 2001, but see Graça et al. 2001

Fabre and Chauvet 1998, Fleituch 2001

Pozo 1993

Meyer 1980, Smith 1986, Casas 1996

Reice 1974

Rounick and Winterbourn 1983

Rosemond et al. 1998, Usio 2000, Konishi et al. 2001, Schofield et al. 2001

Webster and Benfield 1986, Bunn 1988, Garden and Davies 1988, 1989, McArthur et al. 1988, Short and Smith 1989, Lopez et al. 2001, Menendez et al. 2003

Reice 1974, Triska and Buckley 1978, Herbst 1980, Meyer 1980, Chauvet 1988, Chergui and Pattee 1990, Rader et al. 1994, Niyogi et al. 2003

Allard and Moreau 1986, Collier and Winterbourn 1987, Garden and Davies 1989, Griffith and Perry 1994, Rowe et al. 1996, Dangles and Guerold 1998, 2001, Siefert and Mutz 2001, Dangles and Chauvet 2003, Riipinen et al. 2008

Rosset et al. 1982

Elwood et al. 1981, Meyer and Johnson 1983, Young et al. 1994, Suberkropp and Chauvet 1995, Pozo et al. 1998, Robinson and Gessner 2000, Graça et al. 2001, Huryn et al. 2002,

Rosemond et al. 2002, Gulis and Suberkropp 2003, Niyogi et al. 2003, Menendez et al. 2003, Gulis et al. 2006, Hagen et al. 2006, Paul et al. 2006, Mesquita et al. 2007

Pascoal et al. 2001, 2003, but see Raviraja et al. 1998

Schultheis and Hendricks 1999, Sridhar et al. 2001, Niyogi et al. 2001, but see Nelson 2000

Wallace et al. 1982, Kreutzweiser et al. 1998

Webster and Waide 1982, Griffith and Perry 1991, Whiles and Wallace 1997, Benfield et al. 2001, but see Bird and Kaushik 1992

Webster and Benfield 1986, Enriquez et al. 1993, Ostrofsky 1993, 1997, Campbell and Fuchshuber 1995, Hutchens and Benfield 2000, Royer and Minshall 2001, Chadwick and Huryn 2003, Riipinen et al. 2008

Short and Ward 1980, Casas et al. 2000, Nelson and Roline 2000

Gelroth and Marzolf 1978

Dewson et al. 2007 leaf material is a measure of leaf toughness as the force required to drive a blunt metal pin through a leaf (Suberkropp and Klug 1980, Young et al. 1994, Quinn et al. 2000, Huryn et al. 2002, Chadwick and Huryn 2003, Niyogi et al. 2003). This force can be measured in Newtons with a commercially available penetrometer or as the mass (lead shot or water added to a container directly above the pin) required to force the pin through the leaf. Other measurements, such as concentrations of polysaccharides, total $\mathrm{N}$, protein, tannin, lignin, and ergosterol (an indicator of fungal biomass) in the leaves (Suberkropp et al. 1976) also could be made (Boulton and Boon 1991). Microbial growth and activity can be measured as radioactive thymidine uptake and respiration rates, respectively. These measurements can help determine the relative 
importance of bacteria, fungi, and invertebrates, but many are time-consuming and require specialized equipment and, therefore, probably are beyond the scope of monitoring programs that use leaf breakdown as a routine measurement of river ecosystem health.

The simplest method of reporting breakdown rates is to use the percentage of the initial mass of leaf material remaining after a certain time period. This method assumes that decomposition is linear and that a constant amount of material is lost throughout the decomposition process. Studies on leaf breakdown often report exponential decay of the leaf material, where a constant proportion of the material remaining at any time is lost throughout the decomposition process. In these situations, breakdown rates are more accurately described in terms of an exponential decay coefficient $(k)$ than by percentage of mass remaining (Petersen and Cummins 1974). However, exponential decay coefficients represent a simplification of the actual process in streams (Boulton and Boon 1991). Leaf decay begins with the fast leaching of soluble compounds, followed by relatively fast decay of the fleshy parts of the leaf. The tougher veins decompose at the slowest rates. Therefore, at least 3 distinct decay rates might occur as a leaf decomposes. This fact can cause problems when trying to interpret decomposition rates, especially if the deployment period is fixed with only a single retrieval time. When only initial and final masses (or toughness) are measured, it is impossible to determine whether decomposition was linear or exponential. Nevertheless, we recommend use of exponential decay rates because they are the standard measure reported in the literature.

If natural differences in water temperature are expected between sites, and temperature has been measured continuously throughout the study, then the effect of temperature on decomposition rates can be removed by using degree days, rather than days, as the measurement of time (Minshall et al. 1983).

\section{Ecosystem Metabolism}

\section{Review of factors controlling river metabolism}

River ecosystem metabolism - the combination of gross primary production (GPP; photosynthesis [P]) and ecosystem respiration (ER)-is a measure of how much organic $C$ is produced and consumed in rivers. Algae and other aquatic plants are responsible for primary production, whereas ER measures the rates of respiration of all life, including fish, invertebrates, algae, aquatic plants, and microbes. The ratio of these 2 variables (GPP/ER or P/R) also is informative and provides information on the relative importance of the 2 key sources of energy that fuel river ecosystems- algae and terrestrial organic matter. If organic $\mathrm{C}$ production is greater than C consumption, then organic matter produced within the system probably is supporting the food web, whereas if $\mathrm{C}$ consumption is greater than $\mathrm{C}$ production, then organic matter from upstream or the surrounding catchment probably is maintaining the system (Meyer 1989). Therefore, ecosystem metabolism provides a direct measurement of the food base of river ecosystems and helps to determine their life-supporting capacity.

Ecosystem metabolism is influenced by a wide range of factors. Some factors vary naturally (e.g., longitudinal position in the river, climate), whereas others are influenced primarily by anthropogenic disturbance to ecosystems (e.g., organic pollution, river regulation, toxic chemicals, aquatic plant management). However, many of the factors that control ecosystem metabolism vary as a result of both natural and anthropogenic causes (e.g., light, substrate composition, turbidity, nutrients, $\mathrm{pH}$, riparian vegetation, flow fluctuations). Considerable research has been done on river ecosystem metabolism (Table 2), especially in the last $10 \mathrm{y}$, as improvements in technology have made measurements easier.

The probable effects of natural variation on rates of metabolism must be understood and taken into account when designing monitoring programs or when interpreting data. For example, a key prediction of the river continuum concept is that GPP/ER should change in a predictable manner from the headwaters to the lower reaches of natural river systems (Vannote et al. 1980). This prediction has been tested in many locations and generally has been supported by data (Table 2; Naiman 1983, Bott et al. 1985, Chessman 1985, Naiman et al. 1987, Minshall et al. 1992, McTammany et al. 2003), although some fundamental differences have been seen in grassland/prairie systems (Wiley et al. 1990, Young and Huryn 1996) and in rivers with strong floodplain connections (Junk et al. 1989, Meyer and Edwards 1990). Thus, metabolic rates at potentially impacted sites should be compared with rates measured at (more) pristine sites that are characterized by similar stream order and size.

The amount of light reaching primary producers on the streambed appears to be the main factor influencing GPP in rivers (Bott et al. 1985, Young and Huryn 1999, Mulholland et al. 2001, Fellows et al. 2006). Many factors control the amount of light reaching a particular reach. These factors include the amount and type of riparian vegetation, orientation of the valley, and slope of the banks. Light input also varies with cloud cover and seasonally with changes in day length and sun angle. The amount of light passing through the water column depends on water clarity (Davies-Colley et al. 1992). Shading from riparian 
vegetation is particularly important, and changes associated with leaffall or removal of riparian vegetation can have dramatic effects on stream metabolism. For example, GPP declined 75\% after leaves emerged and shaded the streambed in 2 deciduous forest streams in Tennessee (Hill et al. 2001). Light intensity is unlikely to affect respiration rates directly, but light intensity and ER could be correlated when respiration is mainly associated with algal biomass, which can be abundant in well-lit streams (Bunn et al. 1999). Differences in turbidity and riparian shading could be related to human-induced disturbance to river ecosystems, but natural changes in light input, such as cloud cover and season, should be factored out as much as possible in monitoring programs.

Effects of climate on ecosystem metabolism probably are mediated through light inputs, rather than through water temperature, which is the primary factor affecting leaf breakdown. Increases in temperature (to a certain tolerance limit) should enhance GPP and ER (Phinney and McIntire 1965). However, temperature effects appear weak at the ecosystem scale (DeNicola 1996, Mulholland et al. 2001). We are unaware of any studies that have conclusively shown a link between GPP and temperature in natural streams. However, several studies have suggested modest effects of temperature on ER (Bott et al. 1985, Hill and Gardner 1987, Hedin 1990, Howarth et al. 1992, Sinsabaugh 1997, Hill et al. 1998, 2000, 2002), and many studies have shown that ER is significantly greater in summer than in winter (Webster et al. 1995).

Another point to consider when using metabolism as an index of health is that some factors affect both GPP and ER, whereas others primarily influence only one of these processes (Table 2). For example, GPP appears to be more sensitive to flow fluctuations than does ER, so bed-moving high flows tend to cause dramatic reductions in P/R (Young and Huryn 1996, Uehlinger and Naegeli 1998, Uehlinger 2000, 2006, Uehlinger et al. 2003). Increased light input caused by loss of stream-side vegetation is likely to affect GPP more strongly than ER (Table 2). In contrast, a reduction in connectivity between surface and hyporheic flows should affect ER strongly, because a relatively large proportion of the ER appears to occur in the hyporheic zone (Mulholland et al. 1997, Fellows et al. 2001), without influencing GPP, which occurs primarily on the surface of the streambed.

The presence of particular species that strongly influence the food web does not appear to affect metabolism to the same extent as it does leaf-litter processing. Nevertheless, trophic cascades, in which changes at one trophic level influence other trophic levels, are well known in streams. Biggs et al. (2000) compared periphyton biomass and production among 6 streams with different top-level fish predators (Salmo trutta [brown trout], and Galaxias spp.) to determine the strength and implications of trophic cascading that had been observed in earlier experiments in artificial stream channels (Flecker and Townsend 1994). Periphyton biomass was significantly higher in the trout streams than in the Galaxias streams, but differences in periphyton biomass were not associated with differences in GPP. In a more intensive study at 2 of the same sites, Huryn (1998) observed a $6 \times$ difference in annual net primary production between a trout stream and a Galaxias stream. This result suggests that particular species can sometimes affect metabolism.

Human-induced stressors often tend to co-occur, and co-occurring effects might be either complementary or antagonistic. For example, agricultural development often is associated with removal of riparian vegetation and with increased nutrient and sediment delivery to streams. Removal of riparian vegetation increases light available for GPP, and this effect is enhanced by an increased supply of nutrients. High rates of GPP and ER in response to abundant light and nutrient levels have been observed in agricultural streams and rivers (Wiley et al. 1990, Wilcock et al. 1998, Young and Huryn 1999). However, increased concentrations of suspended fine sediment and turbidity tend to counteract these positive effects and lead to declines in GPP at sites where the combination of water depth and turbidity restricts light availability at the riverbed (Wiley et al. 1990, Young and Huryn 1996). Similar antagonistic effects might occur in streams receiving waste discharges in which increased organic $C$ would tend to increase ER, but industrial toxins might reduce GPP and ER (Rama Rao et al. 1979).

\section{Measurement of river ecosystem metabolism}

GPP involves uptake of $\mathrm{CO}_{2}$ and release of $\mathrm{O}_{2}$ into the water, whereas ER is essentially the reverse process. Therefore, ecosystem metabolism can be measured using changes in either $\mathrm{O}_{2}$ or $\mathrm{CO}_{2}$ (Bott et al. 1978). $\mathrm{CO}_{2}$ is relatively difficult to measure directly in water, so some researchers have measured $\mathrm{pH}$, which closely corresponds with $\mathrm{CO}_{2}$ (Simonsen and Harremoes 1978, Cushing and Wolf 1984). Radioactive ${ }^{14} \mathrm{CO}_{2}$ uptake also can be used to measure rates of photosynthesis (Bott and Ritter 1981), but we recommend using changes in dissolved $\mathrm{O}_{2}$ because this variable is relatively easy to measure, and the magnitude of $\mathrm{O}_{2}$ change is typically large.

Metabolism can be estimated by measuring natural changes in $\mathrm{O}_{2}$ concentration in the river, or by enclosing part of the river in an air-tight chamber and measuring 
TABLE 2. Expected patterns in gross primary productivity (GPP) and ecosystem respiration (ER), and in the ratio of photosynthesis to respiration $(P / R)$ in relation to natural variation and responses to environmental stressors.

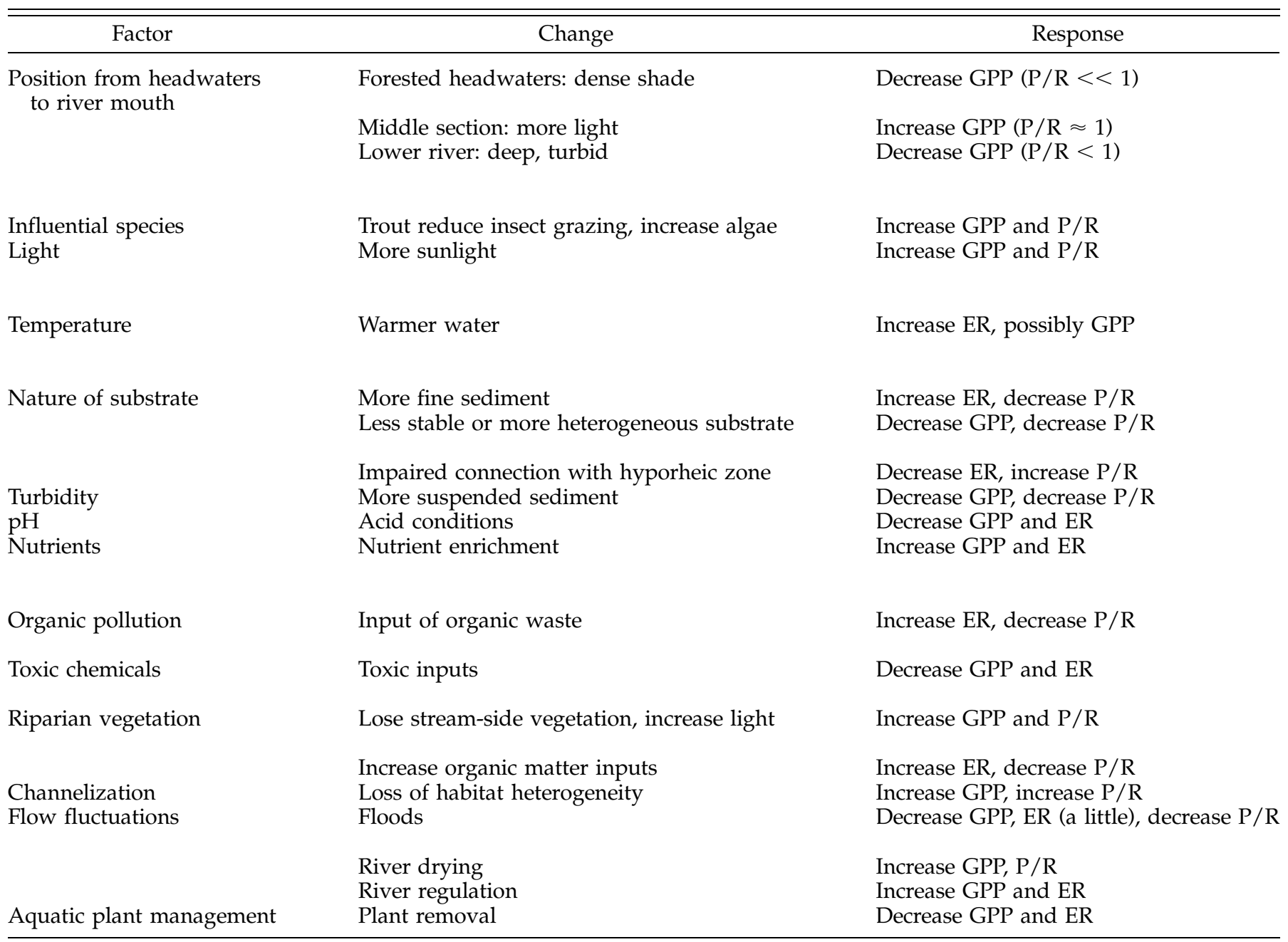

$\mathrm{O}_{2}$ changes in the chamber. Open-system methods have the advantage that they include the whole ecosystem, and, in many situations, measurements are relatively simple and require just 1 data-logging $\mathrm{O}_{2}$ meter (Owens 1974, Young and Huryn 1996). $\mathrm{O}_{2}$ concentrations are measured at regular intervals over at least one 24-h period, and changes in concentration are related to $\mathrm{O}_{2}$ input via photosynthesis and $\mathrm{O}_{2}$ removal via respiration. The main difficulty with open-system measurements is that they require an estimate of the amount of $\mathrm{O}_{2}$ diffusing between the air and water (reaeration). Reaeration rates can be estimated relatively easily in most rivers and streams from the $\mathrm{O}_{2}$ record (Owens 1974, Kosinski 1984, McBride 2002) or by applying empirical equations that use mean reach depth and mean velocity to estimate reaeration coefficients (Wilcock 1982, Young and Huryn 1999). However, morecomplicated techniques involving injection of tracer gases are required in small, turbulent streams with low primary productivity (Marzolf et al. 1994, Young and Huryn 1998, 1999). We think that open-system $\mathrm{O}_{2}$ change methods are the most appropriate methods for routine monitoring of ecosystem metabolism.

Measurements of metabolism made within chambers usually also use changes in $\mathrm{O}_{2}$ concentration over at least one 24-h period (Bott et al. 1978). However, ER and maximum GPP can be estimated over shorter periods by comparing $\mathrm{O}_{2}$ changes in chambers exposed to high light intensities with those in artificially darkened chambers (Hickey 1988). Chamber measurements have been used to assess the contribution of different components of river ecosystems to overall metabolism (Naiman 1983, Mulholland et al. 1997, Naegeli and Uehlinger 1997, Oliver and Merrick 2006). The $\mathrm{O}_{2}$ changes are measured within an air-tight chamber, so estimates of metabolism can be made without measurements of diffusion rates. However, the use of such chambers has many disadvantages: 1) material placed 
TABLE 2. Extended.

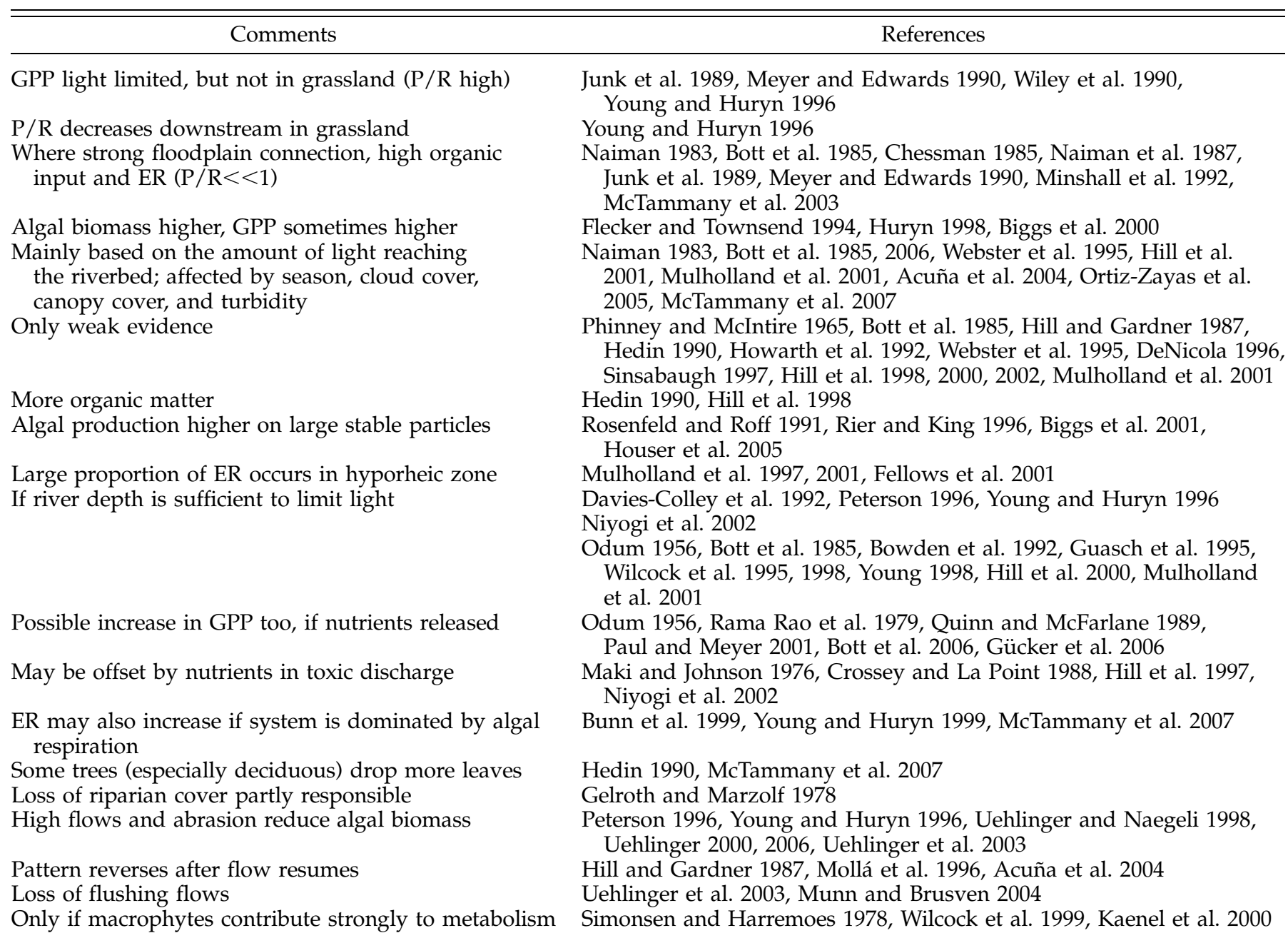

within the chamber invariably is disturbed during the process; 2) water velocity, light, nutrient concentrations, and temperature within the chamber differ from natural conditions in the river; and 3) errors can occur when trying to relate small-scale measurements of different components of the ecosystem to processes occurring at the whole-reach scale. Considerable effort has been made to overcome some of these disadvantages (Bott et al. 1997, Dodds and Brock 1998, Bunn et al. 1999, Uzarski et al. 2001), but many of the problems cannot be solved simply by adjustments to chamber design. Therefore, we do not recommend chambers for use in routine measurements of river ecosystem health.

\section{Discussion}

\section{Relationships of functional measures to ecosystem health}

As with any biological indicator, river managers require guidance regarding the meaning of functional measurements for ecosystem health. Ideally, managers should know the specific values that might indicate a possible transition from "good" to "poor" ecosystem health. Gessner and Chauvet (2002) proposed a tentative framework for assessing functional stream integrity from leaf-litter processing rates (Table 3 ). This framework includes 2 approaches. The $1^{\text {st }}$ compares values at test sites with values at appropriate reference sites and sets impairment criteria based on values at the reference sites. For example, a leaf-litter decay rate at a test site that is within $30 \%$ of the decay rate at reference sites would indicate good ecosystem health, whereas decay rates $<50 \%$ or $>200 \%$ of those at reference sites would indicate severely impaired ecosystem health. Values between the extremes would indicate milder effects. Scores could be assigned to each criterion as a simple way of indicating the health of different sites (Table 3 ).

The $2^{\text {nd }}$ approach compares values at test sites with 
TABLE 3. Framework for assessing functional stream health using leaf-litter processing rates (from Gessner and Chauvet 2002). Scores indicate the health of the test site: $2=$ no evidence of an impact on ecosystem function, $1=$ mild effect on ecosystem function, $0=$ severely impaired ecosystem function. $k_{\mathrm{t}}=$ decomposition rate at test sites, $k_{\mathrm{r}}=$ decomposition rate at reference sites.

\begin{tabular}{lclc}
\hline \hline \multicolumn{1}{c}{ Method } & Assessment parameter & \multicolumn{1}{c}{ Criterion } \\
\hline Comparison with reference & $k_{\mathrm{t}} / k_{\mathrm{r}}$ & $k_{\mathrm{t}} / k_{\mathrm{r}}=0.75-1.33$ & Score \\
& & $k_{\mathrm{t}} / k_{\mathrm{r}}=0.5-0.75$ or $k_{\mathrm{t}} / k_{\mathrm{r}}=1.33-2.0$ & 2 \\
& & $k_{\mathrm{t}} / k_{\mathrm{r}}<0.5$ or $k_{\mathrm{t}} / k_{\mathrm{r}}>2.0$ & 0 \\
Absolute value & $k_{\mathrm{t}}(/ \mathrm{d})$ & $k_{\mathrm{t}}=0.01-0.03$ & $k_{\mathrm{t}}=0.005-0.01$ or $k_{\mathrm{t}}=0.03-0.05$ \\
& & $k_{\mathrm{t}}<0.005$ or $k_{\mathrm{t}} / k_{\mathrm{r}}>0.05$ & 0 \\
\hline
\end{tabular}

set absolute values (Table 3). For example, Gessner and Chauvet (2002) suggested that leaf-litter processing rates between 0.01 and $0.03 / \mathrm{d}$ generally indicate good ecosystem health, whereas values outside this range indicate either mild or severe impairment of ecosystem health (Table 3). However, sensible absolute values cannot be set without knowing the type of leaves used or the characteristics of the test sites. If rivers within a given biomonitoring region were classified into types and sufficient information on breakdown rates in reference streams of each type were obtained, a series of absolute values could be devised for comparison with test sites of the same type.

We extended the framework proposed by Gessner and Chauvet (2002) to assessing ecosystem health based on ecosystem metabolism. We did a metaanalysis of river metabolism data in the scientific literature (Wiley et al. 1990, Young and Huryn 1996, 1999, Webster and Meyer 1997, Wilcock et al. 1998, Young 1998, Mulholland et al. 2001, 2006, Hall and Tank 2003, McTammany et al. 2003, 2007, Houser et al. 2005, Meyer et al. 2005, Ortiz-Zayas et al. 2005, Bott et al. 2006, Gücker et al. 2006), and split study sites into 2 groups. Reference sites drained relatively natural catchments, and impact sites drained intensively modified land. We used data from the reference sites to develop interim criteria for interpreting metabolism data (Fig. 1A-C, Table 4).

We assumed that GPP and ER values between the lower and upper quartiles of the reference-site distributions $\left(25^{\text {th }}-75^{\text {th }}\right.$ percentiles) indicated good ecosystem health, as has been done previously for other biological indices (Gerritsen 1995, Barbour et al. 1996, Maxted et al. 2000). We categorized GPP values outside this range such that values $<25^{\text {th }}$ percentile also indicated good ecosystem health, values between the $75^{\text {th }}$ and $95^{\text {th }}$ percentiles indicated satisfactory ecosystem health, and values $>95^{\text {th }}$ percentile indicated poor ecosystem health (Fig. 1A). We categorized ER values outside the $25^{\text {th }}$ to $75^{\text {th }}$ percentile range such that values between the $5^{\text {th }}$ and $25^{\text {th }}$ percentiles or between the $75^{\text {th }}$ and $95^{\text {th }}$ percentiles indicated satisfactory ecosystem health and values $<5^{\text {th }}$ percentile or $>95^{\text {th }}$ percentile indicated poor ecosystem health (Fig. 1B). The differences between the GPP and ER criteria reflect the fact that low GPP values do not necessarily indicate poor ecosystem health, e.g., small, pristine forested streams can have very low rates of GPP. However, extremely low rates of ER are more likely than low rates of GPP to indicate poor ecosystem health. Our analysis yielded absolute target values that seemed to be applicable for GPP and ER measurements (Table 4). We derived tentative thresholds for comparing test sites with reference sites by comparing the average rates of GPP and ER for the reference sites with the appropriate lower and upper limits of each range. We assigned scores to each criterion as a simple way to indicate ecosystem health of sites (Table 4; Gessner and Chauvet 2002).

We tested whether these criteria could distinguish healthy from unhealthy systems by comparing metabolism data from reference sites with data from impact sites (log-transformed analysis of variance [ANOVA]; Fig. 2A-C). Almost all data from the impact sites indicated either poor or satisfactory health according to the criteria. Data from only 16 of 82 impact sites indicated good ecosystem health. Therefore, our proposed framework has the potential to identify sites where ecosystem metabolism has been impaired.

The framework presented here is very broad and could be tightened by developing criteria based on appropriate local reference sites rather than the broad range of sites used in our meta-analysis. For example, light input and shading affect GPP, and patterns of GPP vs ER differed markedly between reference sites with closed canopies (smaller or forested sites) and open canopies (larger or grassland sites) (log-transformed ANOVA, Fig. 3A, B). Reference sites with closed canopies would provide a more appropriate basis of comparison than reference sites with both open and closed canopies when a study is designed to investigate the effect of loss of riparian vegetation on small forested streams. Similarly, ephemeral streams 

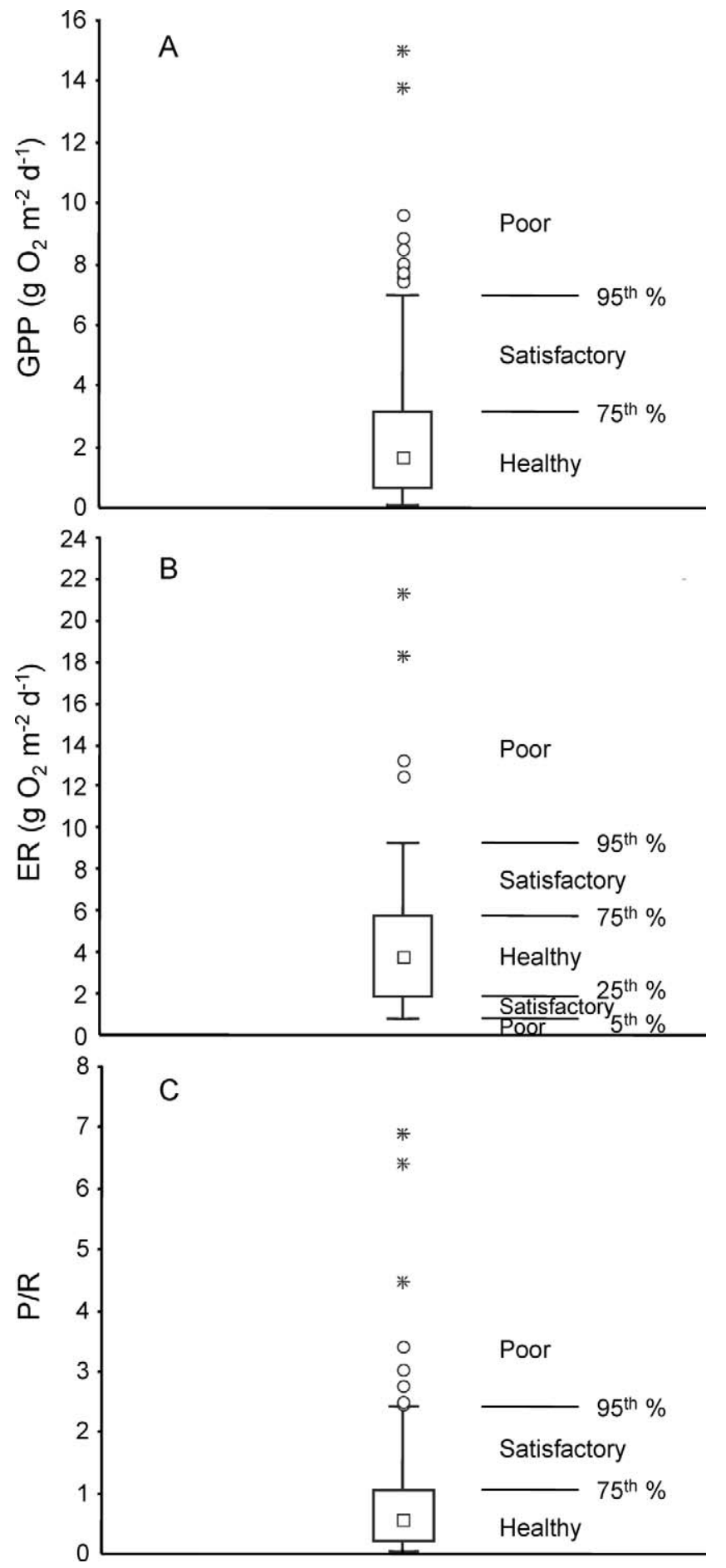

FIG. 1. Distribution of rates of gross primary production (GPP) (A), ecosystem respiration (ER) (B), and the ratio of GPP and ER (P/R) (C) from reference sites $(n=213)$ and proposed criteria that could be used to determine the health of streams. Values were taken from the scientific literature (Wiley et al. 1990, Young and Huryn 1996, 1999, Webster and Meyer 1997, Wilcock et al. 1998, Young 1998, Mulholland et al. 2001, 2006, Hall and Tank 2003, McTammany et al. 2003, 2007, Houser et al. 2005, Meyer et al. 2005, Ortiz-Zayas et al. 2005, Bott et al. 2006, Gücker et al. 2006). have very high rates of ER associated with accumulation of organic matter during periods of low or no flow (Acuña et al. 2004), and conditions at reference sites for these streams should reflect this characteristic.

Other metrics, such as $\mathrm{P} / \mathrm{R}$, also might be useful for detecting particular types of environmental stress where the effects do not apply equally to both GPP and ER (Fig. 1C). For example, P/R was similar at reference and impact sites included in our metaanalysis (log-transformed ANOVA, $p>0.05$; Fig. $2 \mathrm{C})$, but $\mathrm{P} / \mathrm{R}$ clearly differed between reference sites with closed and open canopies (log-transformed ANOVA, $p<0.001$; Fig. 3B).

\section{Advantages and disadvantages as biomonitoring tools}

Leaf decomposition.-Leaf breakdown has specific advantages as a potential bioindicator: 1) Measurement is relatively simple and requires inexpensive equipment that is readily available. 2) Many scientific studies have examined the factors that control leaf breakdown, so responses to natural variation and most stressors can be predicted with confidence. 3) Leaf breakdown can be measured in any aquatic habitat, from tiny streams to large rivers, and the method can be used in lakes, wetlands, and estuaries. 4) Criteria for linking leaf breakdown rates and ecosystem health exist already (Gessner and Chauvet 2002).

Leaf breakdown also has disadvantages as a potential bioindicator: 1) Leaf breakdown is influenced by a wide variety of factors, and this broad response can sometimes make interpretation of results difficult. 2) Leaf breakdown is measured at a specific location in a stream and is indicative of conditions only at that location rather than throughout an entire reach; thus, the method is suited best for detecting small-scale effects of stressors. 3) The meaning of this measurement is not intuitive to the general public; therefore, simple and clear explanations are required to demonstrate how leaf breakdown rates can be used to measure river health.

Ecosystem metabolism.-Metabolism has several specific advantages as a potential bioindicator: 1) Metabolism measurements are representative of the entire reach and cover the range of habitat types present, even though the $\mathrm{O}_{2}$ concentrations used to calculate metabolism are only measured at 1 or 2 specific locations, because of the natural movement and mixing of water in a river. 2) Metabolism directly assesses the balance between energy supply and demand in river ecosystems and, thus, gives an indication of what fuels the ecosystem. 3) Studies of metabolism at one particular site can be planned, conducted, and completed within as little as $2 \mathrm{~d}$, 
TABLE 4. Framework for assessing functional stream health using gross primary productivity (GPP) and ecosystem respiration (ER) data. The scores indicate the health of the test site: $2=$ no evidence of an impact on ecosystem functioning, $1=$ mild effect on ecosystem functioning, $0=$ severely impaired ecosystem functioning; $t=$ test site, $r=$ reference site.

\begin{tabular}{|c|c|c|c|}
\hline Method & Assessment parameter & Criterion & Score \\
\hline & $\mathrm{GPP}_{\mathrm{t}} / \mathrm{GPP}_{\mathrm{r}}$ & $\mathrm{GPP}_{\mathrm{t}} / \mathrm{GPP}_{\mathrm{r}}=2.5-5.0$ & 1 \\
\hline & \multirow[t]{3}{*}{$\mathrm{ER}_{\mathrm{t}} / \mathrm{ER}_{\mathrm{r}}$} & $\mathrm{ER}_{\mathrm{t}} / \mathrm{ER}_{\mathrm{r}}=0.4-1.6$ & 2 \\
\hline & & $\mathrm{ER}_{\mathrm{t}} / \mathrm{ER}_{\mathrm{r}}=0.2-0.4$ or $1.6-2.7$ & 1 \\
\hline & & $\mathrm{ER}_{\mathrm{t}} / \mathrm{ER}_{\mathrm{r}}<0.2$ or $\mathrm{ER}_{\mathrm{t}} / \mathrm{ER}_{\mathrm{r}}>2.7$ & 0 \\
\hline \multirow{4}{*}{ Absolute value } & $\mathrm{GPP}_{\mathrm{t}}\left(\mathrm{g} \mathrm{O}_{2} \mathrm{~m}^{-2} \mathrm{~d}^{-1}\right)$ & $\mathrm{GPP}_{\mathrm{t}}>7.0$ & 0 \\
\hline & \multirow[t]{3}{*}{$\mathrm{ER}_{\mathrm{t}}\left(\mathrm{g} \mathrm{O}_{2} \mathrm{~m}^{-2} \mathrm{~d}^{-1}\right)$} & $\mathrm{ER}_{\mathrm{t}}=1.6-5.8$ & 2 \\
\hline & & $\mathrm{ER}_{\mathrm{t}}=0.8-1.6$ or $\mathrm{ER}_{\mathrm{t}}=5.8-9.5$ & 1 \\
\hline & & $\mathrm{ER}_{\mathrm{t}}<0.8$ or $\mathrm{ER}_{\mathrm{t}}>9.5$ & 0 \\
\hline
\end{tabular}

assuming the necessary equipment is available. 4) Metabolism measurements are closely associated with $\mathrm{O}_{2}$ dynamics within a river, and even raw $\mathrm{O}_{2}$ measurements are of interest for assessments of river ecosystem health. 5) The reason for measuring $\mathrm{O}_{2}$ concentrations in rivers is easily explained to members of the general public.

Metabolism also has potential disadvantages as a potential bioindicator: 1) At least 1 data-logging $\mathrm{O}_{2}$ meter is required to make metabolism measurements feasible for biomonitoring, and this equipment is expensive. 2) Measurements of $\mathrm{O}_{2}$ concentration are required over at least a 24-h period; therefore, equipment usually must be left unattended at the sampling site for several hours, with potential losses from theft, vandalism, or sudden changes in flow. 3) Metabolism is difficult to measure in small, turbulent streams with low productivity (e.g., Young and Huryn 1999), and this difficulty limits use of this method for routine biomonitoring in such streams.

\section{Summary and Recommendations}

A variety of ecosystem processes potentially could be used as functional indicators of river ecosystem health. However, in our opinion, rates of organic matter decomposition and ecosystem metabolism best meet the requirements of good indicators and, thus, offer the most potential as indicators of the functional aspects of river ecosystem health. These indicators should be seen as complementary to traditional monitoring tools that rely on structural measures. Measurement of both structural and functional aspects provides a more complete picture of ecosystem health than either aspect alone. Our review of the factors controlling these ecosystem processes should help to inform predictions of how the processes will respond to stressors.

We also outlined a framework for interpreting functional measures in terms of ecosystem health. We extended the approach used by Gessner and Chauvet (2002) for interpreting leaf breakdown rates to interpreting ecosystem metabolism on the basis of absolute target values or the degree of departure of measurements at test sites from measurements at equivalent reference sites. Use of absolute values seems to be well suited to metabolism measurements, but the criteria could be tightened by restricting the reference sites used to establish the statistical distributions to sites that are similar to the test sites.

Leaf breakdown and ecosystem metabolism are affected by a wide range of factors, both anthropogenic and natural. The problem of separating responses to natural and anthropogenic factors is not insurmountable. Stream invertebrate communities also are affected by a wide range of natural and anthropogenic factors but have been used successfully for biomonitoring purposes throughout the world. Where possible, naturally varying factors known to influence rates of decomposition or metabolism, such as water temperature, light, or nutrient concentrations, should be measured in the field, and statistical techniques, such as analysis of covariance, should be used to account for their effects during data analysis. Measures of antecedent conditions, such as time since the last bed-moving flood, also should be incorporated into data analysis because ecosystem metabolism, in particular, shows strong successional patterns following these natural disturbances (Uehlinger 2000, 2006). Alternatively, sampling could be avoided during the first 2 to 3 wk following a bed-moving flood to allow ecosystem function to recover to normal levels.

Accumulation of local data collected with standard 


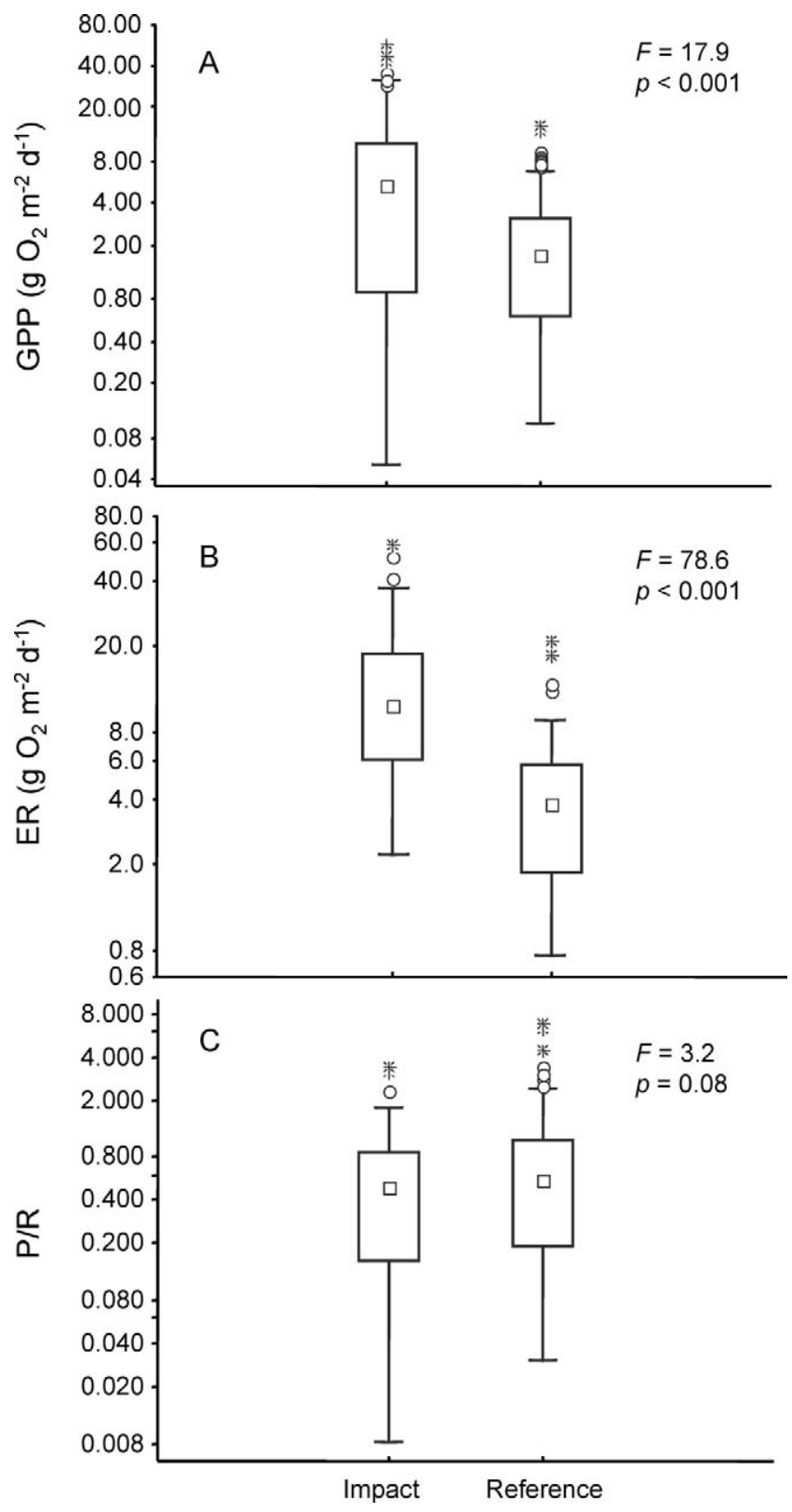

FIG. 2. Comparison of rates of gross primary production (GPP) (A), ecosystem respiration (ER) (B), and the ratio GPP/ER (P/R) $(\mathrm{C})$ between reference sites $(n=213)$ and impact sites $(n=82)$ draining intensively modified land. Values were taken from references listed in Fig. 1.

field procedures throughout a selected monitoring region should allow increasingly meaningful interpretations of results of individual studies. Local databases could be used to fine-tune tentative criteria for detecting impairment. This process has already begun in Europe (see Gulis et al. 2006, Lecerf et al. 2006, Izagirre et al. 2008). Database development should include trials that address a wide range of stress intensities to identify potentially nonlinear responses
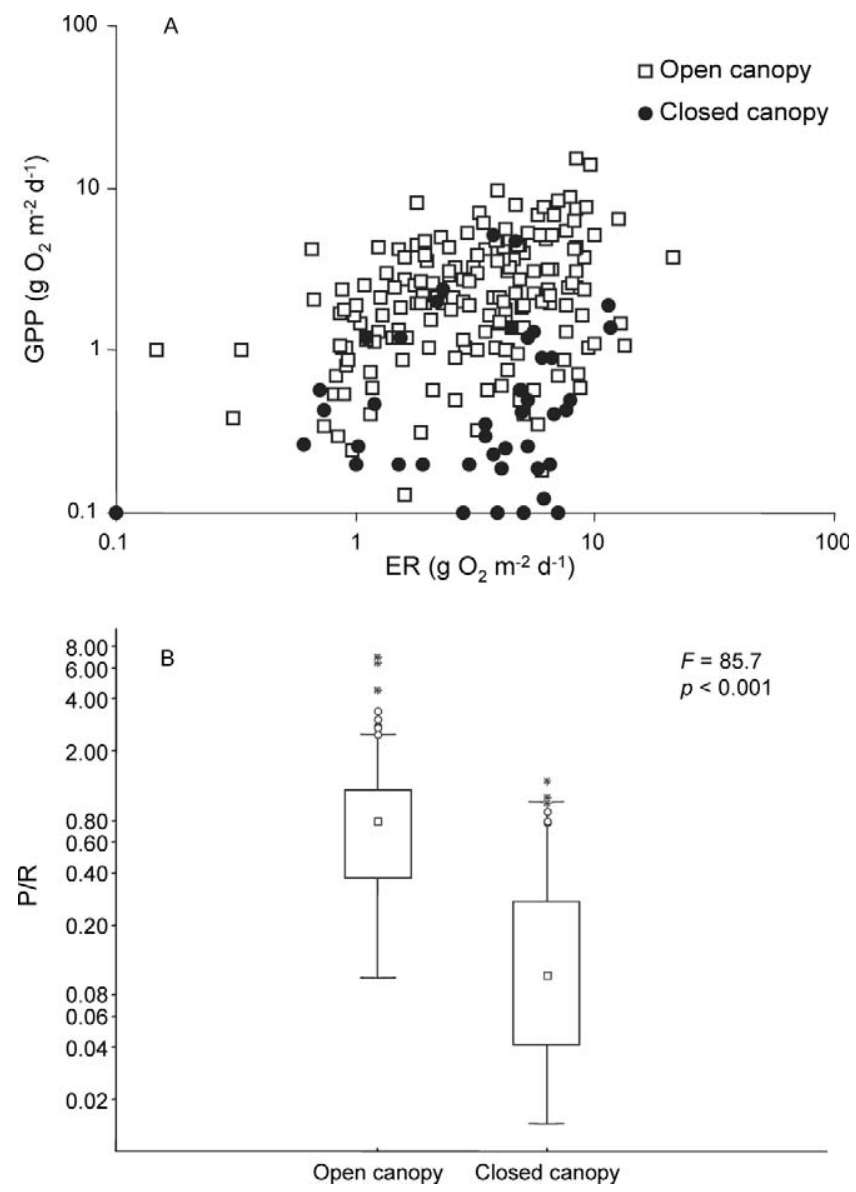

FIG. 3. Plots of ecosystem respiration (ER) vs gross primary production (GPP) (A) and the ratio GPP/ER (P/R) (B) for reference sites with closed $(n=48)$ and open canopies $(n=165)$. Values were taken from references listed in Fig. 1.

and to refine estimates of variability among reference sites. Further research on the influence of interacting stressors on indicator responses (e.g., Niyogi et al. 2003, Hagen et al. 2006, McTammany et al. 2008) also would be valuable.

We recommend methods for measuring organic matter decomposition and ecosystem metabolism that are economical and that limit method-related variability. Use of artificial substrates, such as cotton strips or wooden sticks, instead of highly variable natural leaves reduces within-site variation in decay rates and increases power to detect differences among sites (Tiegs et al. 2007). Methodological improvements also might aid interpretation of results. For example, fluorescence-quenching $\mathrm{O}_{2}$ probes can be deployed for long periods without calibration and stirring problems, so continuous open-system measurements of $\mathrm{O}_{2}$ concentrations should become more feasible and, therefore, more common. These data will allow better understanding of natural variability in rates of 
ecosystem metabolism and, therefore, will increase our ability to characterize correctly rates that indicate healthy or unhealthy conditions.

\section{Acknowledgements}

We thank Scott Kerr for assisting with the literature search on leaf-litter decomposition. Comments from Joe Hay, John Stark, Rowan Strickland, Dev Niyogi, Matt Whiles, and 2 anonymous referees helped improve earlier versions of the manuscript. Funding for the preparation of this paper was kindly provided by the New Zealand Minister for the Environment's Sustainable Management Fund (Contract 2208), Cawthron Institute, Hawke's Bay Regional Council, Greater Wellington Regional Council, Tasman District Council, Horizons Regional Council, Marlborough District Council, Fish and Game New Zealand, Taranaki Regional Council, and Environment Waikato.

\section{Literature Cited}

Acuña, V., A. Giorgi, I. Muñoz, U. Uehlinger, and S. Sabater. 2004. Flow extremes and benthic organic matter shape the metabolism of a headwater Mediterranean stream. Freshwater Biology 49:960-971.

Allard, M., AND G. Moreau. 1986. Leaf decomposition in an experimentally acidified stream channel. Hydrobiologia 139:109-117.

Baldy, V., M. O. Gessner, and E. Chauvet. 1995. Bacteria, fungi and the breakdown of leaf litter in a large river. Oikos 74:93-102.

Barbour, M. T., J. Gerritsen, G. E. Griffith, R. Frydenborg, E. McCarron, J. S. White, and M. L. Bastian. 1996. A framework for biological criteria for Florida streams using benthic macroinvertebrates. Journal of the North American Benthological Society 15:185-211.

Barbour, M. T., J. Gerritsen, B. D. SNyder, and J. B. Stribling. 1999. Rapid bioassessment protocols for use in streams and wadeable rivers: periphyton, benthic macroinvertebrates and fish. $2^{\text {nd }}$ edition. EPA 841-B-99-002. Office of Water, US Environmental Protection Agency, Washington, DC.

Bärlocher, F., C. CAnHoto, and M. A. S. GraçA. 1995. Fungal colonization of alder and eucalypt leaves in two streams in central Portugal. Archiv für Hydrobiologie 133:457470.

BENFIELD, E. F. 1996. Leaf breakdown in stream ecosystems. Pages 579-590 in F. R. Hauer and G. A. Lamberti (editors). Methods in stream ecology. Academic Press, San Diego, California.

Benfield, E. F., J. R. Webster, J. L. Tank, and J. J. Hutchens. 2001. Long-term patterns in leaf breakdown in streams in response to watershed logging. International Review of Hydrobiology 86:467-474.

Bernhardt, E. S., R. O. Hall, And G. E. LiKens. 2002. Wholesystem estimates of nitrification and nitrate uptake in streams of the Hubbard Brook Experimental Forest. Ecosystems 5:419-430.

Biggs, B. J. F., M. J. Duncan, A. M. Suren, And J. R. HolomuzKi. 2001. The importance of bed sediment stability to benthic ecosystems of streams. Pages 423-449 in M. P. Mosley (editor). Gravel bed rivers. New Zealand Hydrological Society, Wellington, New Zealand.

Biggs, B. J. F., S. N. Francoeur, A. D. Huryn, R. G. Young, C. J. ArbuCKLE, AND C. R. TownSEND. 2000. Trophic cascades in streams: effects of nutrient enrichment on autotrophic and consumer benthic communities under two different fish predation regimes. Canadian Journal of Fisheries and Aquatic Sciences 57:1380-1394.

BIRD, G. A., AND N. K. KAUSHIK. 1992. Invertebrate colonization and processing of maple leaf litter in a forested and an agricultural reach of a stream. Hydrobiologia 234:6577.

Bотт, T. L. 1996. Primary productivity and community respiration. Pages 533-556 in F. R. Hauer and G. A. Lamberti (editors). Methods in stream ecology. Academic Press, San Diego, California.

Bott, T. L., J. T. Brock, A. BaAttrup-Pedersen, P. A. Chambers, W. K. Dodds, K. T. Himbeault, J. R. Lawrence, D. Planas, E. SNYDER, AND G. M. WolfaARdT. 1997. An evaluation of techniques for measuring periphyton metabolism in chambers. Canadian Journal of Fisheries and Aquatic Sciences 54:715-725.

Bott, T. L., J. T. Brock, C. E. Cushing, S. V. Gregory, D. King, AND R. C. PEtersen. 1978. A comparison of methods for measuring primary productivity and community respiration in streams. Hydrobiologia 60:3-12.

Bott, T. L., J. T. Brock, C. S. Dunn, R. J. Naiman, R. W. Ovink, AND R. C. Petersen. 1985. Benthic community metabolism in four temperate stream systems: an interbiome comparison and evaluation of the river continuum concept. Hydrobiologia 123:3-45.

Bott, T. L., D. S. Montgomery, J. D. Newbold, D. B. Arscott, C. L. Dow, A. K. Aufdenkampe, J. K. Jackson, and L. A. KaPLAN. 2006. Ecosystem metabolism in streams of the Catskill Mountains (Delaware and Hudson River watersheds) and Lower Hudson Valley. Journal of the North American Benthological Society 25:1018-1044.

BOTT, T. L., AND F. P. RITTER. 1981. Benthic algal productivity in a piedmont stream measured by ${ }^{14} \mathrm{C}$ and dissolved oxygen change procedures. Journal of Freshwater Ecology 1:267-278.

Boulton, A. J. 1999. An overview of river health assessment: philosophies, practice, problems and prognosis. Freshwater Biology 41:469-479.

Boulton, A. J., AND P. I. Boon. 1991. A review of methodology used to measure leaf litter decomposition in lotic environments: time to turn over a new leaf? Australian Journal of Marine and Freshwater Research 42:1-43.

Boulton, A. J., AND J. M. QuinN. 2000. A simple and versatile technique for assessing cellulose decomposition potential in floodplain and riverine sediments. Archiv für Hydrobiologie 150:133-151.

Bowden, W. B., B. J. Petersen, J. C. Finlay, And J. Tucker. 1992. Epilithic chlorophyll $a$, photosynthesis, and respiration in 
control and fertilised reaches of a tundra stream. Hydrobiologia 240:121-131.

Brown, A. V., AND P. P. BRUSsock. 1991. Comparisons of benthic invertebrates between riffles and pools. Hydrobiologia 220:99-108.

Buffagni, A., AND E. Comin. 2000. Secondary production of benthic communities at the habitat scale as a tool to assess ecological integrity in mountain streams. Hydrobiologia 422:183-195.

BunN, S. E. 1988. Processing of leaf litter in a northern jarrah forest stream, Western Australia. 1. Seasonal differences. Hydrobiologia 162:201-210.

BunN, S. E., AND P. M. DAvies. 2000. Biological processes in running waters and their implications for the assessment of ecological integrity. Hydrobiologia 422:61-70.

BunN, S. E., P. M. Davies, AND T. D. Mosisch. 1999. Ecosystem measures of river health and their response to riparian and catchment degradation. Freshwater Biology 41:333345.

Campbell, I. C., AND L. Fuchshuber. 1995. Polyphenols, condensed tannins, and processing rates in tropical and temperate leaves in an Australian stream. Journal of the North American Benthological Society 14:174-182.

CASAS, J. J. 1996. Environmental patchiness and processing of maple leaf litter in a backwater of a mountain stream: riffle area vs debris dams. Archiv für Hydrobiologie 136: 489-508.

Casas, J. J., C. Zamora-Munoz, F. Archila, and J. AlbaTERCEDOR. 2000. The effect of a headwater dam on the use of leaf bags by invertebrate communities. Regulated Rivers 16:577-591.

Chadwick, M. A., And A. D. Huryn. 2003. Effect of a wholecatchment $\mathrm{N}$ addition on stream detritus processing. Journal of the North American Benthological Society 22: 194-206.

CHauvet, E. 1988. Influence of the environment on willow leaf litter decomposition in the alluvial corridor of the Garonne River. Archiv für Hydrobiologie 112:317-386.

Chergui, H., And E. Pattee. 1988. The impact of benthic invertebrates on the breakdown of poplar leaves in the network of a large European river. Archiv für Hydrobiologie 113:15-25.

Chergui, H., And E. PatteE. 1990. The influence of season on the breakdown of submerged leaves. Archiv für Hydrobiologie 120:1-12.

Chergui, H., And E. Pattee. 1991. Breakdown of allochthonous leaves in the catchment of the lower Moulouya River in Morocco. Acta Oecologica 12:543-560.

Chessman, B. C. 1985. Estimates of ecosystem metabolism in the La Trobe River, Victoria. Australian Journal of Marine and Freshwater Research 36:873-880.

Collier, K. J., AND M. J. Winterbourn. 1987. Breakdown of kamahi leaves in four South Westland streams. Mauri Ora 14:33-42.

Crossey, M. J., AND T. W. LA Point. 1988. A comparison of periphyton community structural and functional responses to heavy metals. Hydrobiologia 162:109-121.

Cushing, C. E., AND E. G. Wolf. 1984. Primary production in
Rattlesnake Springs, a cold desert spring-stream. Hydrobiologia 114:229-236.

Dangles, O., And E. Chauvet. 2003. Effects of stream acidification on fungal biomass in decaying beech leaves and leaf palatability. Water Research 37:533-538.

Dangles, O., AND F. Guerold. 1998. A comparative study of beech leaf breakdown, energetic content, and associated fauna in acidic and non-acidic streams. Archiv für Hydrobiologie 144:25-39.

DANGles, O., AND F. Guerold. 2001. Linking shredders and leaf litter processing: insights from an acidic stream study. International Review of Hydrobiology 86:395-406.

Dangles, O., F. Guerold, And P. Usseglio-Polatera. 2001. Role of transported particulate organic matter in the macroinvertebrate colonization of litter bags in streams. Freshwater Biology 46:575-586.

DAVIES, S. P., AND S. K. JACKSON. 2006. The biological condition gradient: a descriptive model for interpreting change in aquatic ecosystems. Ecological Applications 16:12511266.

Davies-Colley, R. J., C. W. Hickey, J. M. Quinn, and P. A. Ryan. 1992. Effects of clay discharges on streams. I. Optical properties and epilithon. Hydrobiologia 248:215-234.

DeNicola, D. M. 1996. Periphyton responses to temperature at different ecological levels. Pages 149-181 in R. J. Stevenson, M. L. Bothwell, and R. L. Lowe (editors). Algal ecology: freshwater benthic ecosystems. Academic Press, San Diego, California.

Dewson, Z. S., A. B. W. James, and R. G. Death. 2007. Stream ecosystem functioning under reduced flow conditions. Ecological Applications 17:1797-1808.

DodDs, W. K., AND J. BRock. 1998. A portable flow chamber for in situ determination of benthic metabolism. Freshwater Biology 39:49-59.

EgGLISHAW, H. J. 1972. An experimental study of the breakdown of cellulose in fast-flowing streams. Memorie dell'Istituto Italiano di Idrobiologia Supplement 29:405428.

Elwood, J. W., J. D. Newbold, A. F. Trimble, and R. W. Stark. 1981. The limiting role of phosphorus in a woodland stream ecosystem: effects of $\mathrm{P}$ enrichment on leaf decomposition and primary producers. Ecology 62:146158.

Enriquez, S., C. M. Duarte, And K. SAnd-Jensen. 1993. Patterns in decomposition rates among photosynthetic organisms: the importance of detritus C:N:P content. Oecologia (Berlin) 94:457-471.

FABRe, E., AND E. Chauvet. 1998. Leaf breakdown along an altitudinal stream gradient. Archiv für Hydrobiologie 141:167-179.

Fellows, C. S., J. E. Clapcott, J. W. Udy, S. E. BunN, B. D. Harch, M. J. Smith, AND P. M. DAvies. 2006. Benthic metabolism as an indicator of stream ecosystem health. Hydrobiologia 572:71-87.

Fellows, C. S., H. M. Valett, and C. N. Dahm. 2001. Wholestream metabolism in two montane streams: contribution of the hyporheic zone. Limnology and Oceanography 46:523-532.

FleCKER, A. S., AND C. R. TownSEND. 1994. Community-wide 
consequences of trout introduction in New Zealand streams. Ecological Applications 4:798-807.

Fleituch, T. 2001. Beech leaf break-down and POM storage along an altitudinal stream gradient. International Review of Hydrobiology 86:515-525.

GARDEN, A., AND R. W. DAVIES. 1988. Decay rates of autumn and spring leaf litter in a stream and effects on growth of a detritivore. Freshwater Biology 19:297-303.

GARDEn, A., AND R. W. DAVIES. 1989. Decomposition of leaf litter exposed to simulated acid rain in a buffered lotic system. Freshwater Biology 22:33-44.

Gelroth, J. V., And G. R. Marzolf. 1978. Primary production and leaf-litter decomposition in natural and channelized portions of a Kansas stream. American Midland Naturalist 99:238-243.

Gerritsen, J. 1995. Additive biological indices for resource management. Journal of the North American Benthological Society 14:451-457.

Gessner, M. O., and E. Chauvet. 2002. A case for using litter breakdown to assess functional stream integrity. Ecological Applications 12:498-510.

Gessner, M. O., C. T. Robinson, AND J. V. WARD. 1998. Leaf breakdown in streams of an alpine glacial floodplain: dynamics of fungi and nutrients. Journal of the North American Benthological Society 17:403-419.

Gonzalez, J. M., A. Basaguren, And J. Pozo. 1998. Mechanisms involved in leaf litter processing: influence of mesh bag size. Pages 89-97 in G. Bretschko and J. Helesic (editors). Advances in river bottom ecology. Backhuys Publishers, Leiden, Netherlands.

Graça, M. A. S., C. Cressa, M. O. Gessner, M. J. Feio, K. A. CAllies, AND C. Barrios. 2001. Food quality, feeding preferences, survival and growth of shredders from temperate and tropical streams. Freshwater Biology 46: 947-957.

Griffith, M. B., AND S. A. Perry. 1991. Leaf pack processing in two Appalachian mountain streams draining catchments with different management histories. Hydrobiologia 220: 247-254.

Griffith, M. B., AND S. A. Perry. 1994. Fungal biomass and leaf litter processing in streams of different water chemistry. Hydrobiologia 294:51-61.

Guasch, H., E. Martí, AND S. SABATER. 1995. Nutrient enrichment effects on biofilm metabolism in a Mediterranean stream. Freshwater Biology 33:373-383.

GüCKer, B., M. Brauns, AND M. T. Pusch. 2006. Effects of wastewater treatment plant discharge on ecosystem structure and function of lowland streams. Journal of the North American Benthological Society 25:313-329.

Gulis, V., V. Ferreira, AND M. A. S. GraçA. 2006. Stimulation of leaf litter decomposition and associated fungi and invertebrates by moderate eutrophication: implications for stream assessment. Freshwater Biology 51:1655-1669.

Gulis, V., AND K. Suberkropr. 2003. Leaf litter decomposition and microbial activity in nutrient-enriched and unaltered reaches of a headwater stream. Freshwater Biology 48: 123-134.

HaApala, A., T. MuotKa, And A. MarkKola. 2001. Breakdown and macroinvertebrate and fungal colonization of alder, birch, and willow leaves in a boreal forest stream. Journal of the North American Benthological Society 20: 395-407.

Hagen, E. M., J. R. Webster, And E. F. Benfield. 2006. Are leaf breakdown rates a useful measure of stream integrity along an agricultural landuse gradient? Journal of the North American Benthological Society 25:330-343.

Hall, R. O., AND J. L. TANK. 2003. Ecosystem metabolism controls nitrogen uptake in streams in Grand Teton National Park, Wyoming. Limnology and Oceanography 48:1120-1128.

Hedin, L. O. 1990. Factors controlling sediment community respiration in woodland stream ecosystems. Oikos 57: 94-105.

Herbst, G. N. 1980. Effects of burial on food value and consumption by aquatic invertebrates in a lowland forest stream. Oikos 35:411-424.

HiCKEY, C. W. 1988. Benthic chamber for use in rivers: testing against oxygen mass balance. American Society of Civil Engineers Journal of Environmental Engineering 114: 828-845.

Hieber, M., AND M. O. Gessner. 2002. Contribution of stream detrivores, fungi and bacteria to leaf breakdown based on biomass estimates. Ecology 83:1026-1038.

Hildrew, A. G., C. R. Townsend, J. Francis, And K. Finch. 1984. Cellulose decomposition in streams of contrasting $\mathrm{pH}$ and its relationship with invertebrate community structure. Freshwater Biology 14:323-328.

Hill, B. H., AND T. J. GARDNER. 1987. Benthic metabolism in a perennial and an intermittent Texas prairie stream. Southwestern Naturalist 32:305-311.

Hill, B. H., T. J. Gardner, O. F. Ekisola, and G. M. Henebry. 1992. Microbial use of leaf litter in prairie streams. Journal of the North American Benthological Society 11: 11-19.

Hill, B. H., R. K. Hall, P. Husby, A. T. Herlihy, and M. Dunne. 2000. Interregional comparisons of sediment microbial respiration in streams. Freshwater Biology 44:213-222.

Hill, B. H., A. T. Herlihy, AND P. R. KaufmanN. 2002. Benthic microbial respiration in Appalachian Mountain, Piedmont, and Coastal Plain streams of the eastern U.S.A. Freshwater Biology 47:185-194.

Hill, B. H., A. T. Herlihy, P. R. Kaufmann, and R. L. SinSABAUGH. 1998. Sediment microbial respiration in a synoptic survey of mid-Atlantic region streams. Freshwater Biology 39:493-501.

Hill, B. H., J. M. LazorchaK, F. H. McCormick, and W. T. Willingham. 1997. The effects of elevated metals on benthic community metabolism in a rocky mountain stream. Environmental Pollution 95:183-190.

Hill, W. R., P. J. Mulholland, and E. R. Marzolf. 2001. Stream ecosystem responses to forest leaf emergence in spring. Ecology 82:2306-2319.

Hornberger, G. M., M. G. Kelly, and B. J. Cosby. 1977. Evaluating eutrophication potential from river community productivity. Water Research 11:65-69.

Houser, J. N., P. J. Mulholland, and K. O. Maloney. 2005. Catchment disturbance and stream metabolism: patterns in ecosystem respiration and gross primary production 
along a gradient of upland soil and vegetation disturbance. Journal of the North American Benthological Society 24:538-552.

Howarth, R. W., R. Marino, R. Garritt, and D. Sherman. 1992. Ecosystem respiration and organic matter processing in a large, tidally influenced river: the Hudson River. Biogeochemistry 16:83-102.

HurYN, A. D. 1998. Ecosystem-level evidence for top-down and bottom-up control of production in a grassland stream system. Oecologia (Berlin) 115:173-183.

Huryn, A. D., V. M. Butz Huryn, And C. J. Arbuckle. 2002. Catchment land-use, macroinvertebrates and detritus processing in headwater streams: taxonomic richness versus function. Freshwater Biology 47:401-415.

Hutchens, J. J., AND E. F. Benfield. 2000. Effects of forest defoliation by the gypsy moth on detritus processing in southern Appalachian streams. American Midland Naturalist 143:397-404.

Izagirre, O., U. Agirre, M. Bermejo, J. Pozo, and A. Elosegi. 2008. Environmental controls of whole-stream metabolism identified from continuous monitoring of Basque streams. Journal of the North American Benthological Society 27:252-268.

Jonsson, M., B. Malmovist, and P. O. Hoffsten. 2001. Leaf litter breakdown rates in boreal streams: does shredder species richness matter? Freshwater Biology 46:161-171.

Junk, W. J., P. B. Bayley, And R. E. Sparks. 1989. The flood pulse concept in river-flood plain systems. Pages 110-127 in D. P. Dodge (editor). Proceedings of the International Large River Symposium. Canadian Special Publication Fisheries and Aquatic Sciences 106.

Kaenel, B. R., H. Buehrer, ANd U. Uehlinger. 2000. Effects of aquatic plant management on stream metabolism and oxygen balance in streams. Freshwater Biology 45:85-95.

KonISHI, M., S. NAKANO, AND T. IWATA. 2001. Trophic cascading effects of predatory fish on leaf litter processing in a Japanese stream. Ecological Research 16:415-422.

KosINSKI, R. J. 1984. A comparison of the accuracy and precision of several open-water oxygen productivity techniques. Hydrobiologia 119:139-148.

Kreutzweiser, D. P., D. G. Thompson, B. Staznik, and J. A. SHEPHERD. 1998. Accumulation dynamics of triclopyr ester in aquatic leaf packs and effects on detritivorous insects. Journal of Environmental Quality 27:1138-1147.

Lecerf, A., P. Usseglio-Polatera, J. Y. Charcosset, D. LAmbrigot, B. BRACHT, AND E. Chauvet. 2006. Assessment of functional integrity of eutrophic streams using litter breakdown and benthic invertebrates. Archiv für Hydrobiologie 165:105-126.

Lopez, E. S., I. Pardo, AND N. Felpeto. 2001. Seasonal differences in green leaf breakdown and nutrient content of deciduous and evergreen tree species and grass in a granitic headwater stream. Hydrobiologia 464:51-61.

MAKI, A. W., AND H. E. JOHNSON. 1976. Evaluation of a toxicant on the metabolism of model stream communities. Journal of the Fisheries Research Board of Canada 33: 2740-2746.

Marzolf, E. R., P. J. Mulholland, and A. D. Steinman. 1994. Improvements to the diurnal upstream-downstream dissolved oxygen change technique for determining whole-stream metabolism in small streams. Canadian Journal of Fisheries and Aquatic Sciences 51:1591-1599.

Mathuriau, C., AND E. CHAuvet. 2002. Breakdown of leaf litter in a neotropical stream. Journal of the North American Benthological Society 21:384-396.

Matthews, R. A., A. L. Buikema, J. Cairns, and J. H. Rodgers. 1982. Biological monitoring, Part IIA-receiving system functional methods, relationships and indices. Water Research 16:129-139.

Maxted, J. R., M. T. Barbour, J. Gerritsen, V. Poretti, N. Primrose, A. Silvia, D. Penrose, and R. Renfrow. 2000. Assessment framework for Mid-Atlantic Coastal Plain streams using benthic macroinvertebrates. Journal of North American Benthological Society 19:128-144.

McArthur, J V., J. R. Barnes, B. J. Hanson, and L. G. LefF. 1988. Seasonal dynamics of leaf litter breakdown in a Utah alpine stream. Journal of the North American Benthological Society 13:57-67.

McBride, G. B. 2002. Calculating stream reaeration coefficients from oxygen profiles. American Society of Civil Engineers Journal of Environmental Engineering 128: 384-386.

McTammany, M. E., E. F. Benfield, and J. R. Webster. 2007. Recovery of stream ecosystem metabolism from historical agriculture. Journal of the North American Benthological Society 26:532-545.

Mctammany, M. E., E. F. Benfield, and J. R. Webster. 2008. Effects of agriculture on wood breakdown and microbial biofilm respiration in southern Appalachian streams. Freshwater Biology 53:842-854.

McTammany, M. E., J. R. Webster, E. F. Benfield, and M. A. NeAtrour. 2003. Longitudinal patterns of metabolism in a southern Appalachian river. Journal of the North American Benthological Society 22:359-370.

Menendez, M., O. Hernandez, and F. A. Comin. 2003. Seasonal comparisons of leaf processing rates in two Mediterranean rivers with different nutrient availability. Hydrobiologia 495:159-169.

Mesquita, A., C. Pascoal, and F. Cassio. 2007. Assessing effects of eutrophication in streams based on breakdown of eucalypt leaves. Fundamental and Applied Limnology 168:221-230.

Meyer, J. L. 1980. Dynamics of phosphorus and organic matter during leaf decomposition in a forest stream. Oikos 34:44-53.

Meyer, J. L. 1989. Can P/R ratio be used to assess the food base of stream ecosystems? A comment on Rosenfeld and Mackay (1987). Oikos 54:119-121.

MeYer, J. L. 1997. Stream health: incorporating the human dimension to advance stream ecology. Journal of the North American Benthological Society 16:439-447.

Meyer, J. L., AND R. T. EdWARds. 1990. Ecosystem metabolism and turnover of organic carbon along a blackwater river continuum. Ecology 71:668-677.

MeYer, J. L., AND C. JoHnson. 1983. The influence of elevated nitrate concentration on rate of leaf decomposition in a stream. Freshwater Biology 13:177-183.

Meyer, J. L., M. J. Paul, And W. K. Taulbee. 2005. Stream 
ecosystem function in urbanizing landscapes. Journal of the North American Benthological Society 24:602-612.

Minshall, G. W., R. C. Petersen, T. L. Bott, C. E. Cushing, K. W. Cummins, R. L. Vannote, and J. R. Sedell. 1992. Stream ecosystem dynamics of the Salmon River, Idaho: an $8^{\text {th }}$ order system. Journal of the North American Benthological Society 11:111-137.

Minshall, G. W., R. C. Petersen, K. W. Cummins, T. L. Bott, J. R. Sedell, C. E. Cushing, and R. L. Vannote. 1983. Interbiome comparison of stream ecosystem dynamics. Ecological Monographs 53:1-25.

Mollá, S., L. MaltchiK, C. Casado, and C. Montes. 1996. Particulate organic matter and ecosystem metabolism dynamics in a temporary Mediterranean stream. Archiv für Hydrobiologie 137:59-76.

Mulholland, P. J., C. S. Fellows, J. L. Tank, N. B. Grimm, J. R. Webster, S. K. Hamilton, E. Martí, L. R. Ashrenas, W. B. Bowden, W. K. Dodds, W. H. McDowell, M. J. Paul, And B. J. Peterson. 2001. Inter-biome comparison of factors controlling stream metabolism. Freshwater Biology 46: 1503-1517.

Mulholland, P. J., E. R. Marzolf, J. R. Webster, D. R. Hart, AND S. P. HENDRICKS. 1997. Evidence that hyporheic zones increase heterotrophic metabolism and phosphorus uptake in forest streams. Limnology and Oceanography 42:443-451.

Mulholland, P. J., S. A. Thomas, H. M. Valett, J. R. Webster, AND J. BeAulieu. 2006. Effects of light on $\mathrm{NO}_{3}{ }^{-}$uptake in small forested streams: diurnal and day-to-day variations. Journal of the North American Benthological Society 25:583-595.

Munn, M. D., AND M. A. Brusven. 2004. The influence of Dworshak Dam on epilithic community metabolism in the Clearwater River, USA. Hydrobiologia 513:121-127.

Mutch, R. A., R. J. Steedman, S. B. Berte, and G. Pritchard. 1983. Leaf breakdown in a mountain stream: a comparison of methods. Archiv für Hydrobiologie 97:89-108.

NAEgeli, M. W., AND U. Uehlinger. 1997. Contribution of the hyporheic zone to ecosystem metabolism in a prealpine gravel-bed river. Journal of the North American Benthological Society 16:794-804.

NAIMAN, R. J. 1983. The annual pattern and spatial distribution of aquatic oxygen metabolism in boreal forest watersheds. Ecological Monographs 53:73-94.

Naiman, R. J., J. M. Melillo, M. A. Lock, T. E. Ford, and S. R. REICE. 1987. Longitudinal patterns of ecosystem processes and community structure in a subarctic river continuum. Ecology 68:1139-1156.

Nelson, S. M. 2000. Leaf pack breakdown and macroinvertebrate colonization: bioassessment tools for a highaltitude regulated system? Environmental Pollution 110: 321-329.

Nelson, S. M., AND R. A. Roline. 2000. Leaf litter breakdown in a mountain stream impacted by a hypolimnetic release reservoir. Journal of Freshwater Ecology 15:479-490.

Niyogi, D. K., W. M. Lewis, JR, AND D. M. McKnight. 2001. Litter breakdown in mountain streams affected by mine drainage: biotic mediation of abiotic controls. Ecological Applications 11:506-516.
Niyogi, D. K., W. M. Lewis, JR, AND D. M. McKnight. 2002. Effects of stress from mine drainage on diversity, biomass, and function of primary producers in mountain streams. Ecosystems 5:554-567.

Niyogi, D. K., K. S. Simon, AND C. R. TownSEND. 2003. Breakdown of tussock grass in streams along a gradient of agricultural development in New Zealand. Freshwater Biology 48:1698-1708.

Norris, R. H., AND C. P. HaWkins. 2000. Monitoring river health. Hydrobiologia 435:5-17.

Odum, H. T. 1956. Primary production in flowing waters. Limnology and Oceanography 1:102-117.

Oliver, R. L., ANd C. J. Merrick. 2006. Partitioning of river metabolism identifies phytoplankton as a major contributor in the regulated Murray River (Australia). Freshwater Biology 51:1131-1148.

Ortiz-Zayas, J. R., W. M. Lewis, JR, J. F. Saunders, J. H. McCutchan, AND F. N. Scatena. 2005. Metabolism of a tropical rainforest stream. Journal of the North American Benthological Society 24:769-783.

Ostrofsky, M. L. 1993. Effect of tannins on leaf processing and conditioning rates in aquatic ecosystems: an empirical approach. Canadian Journal of Fisheries and Aquatic Sciences 50:1176-1180.

OstrofsKy, M. L. 1997. Relationship between chemical characteristics of autumn-shed leaves and aquatic processing rates. Journal of the North American Benthological Society 16:750-759.

OWENS, M. 1974. Measurements on non-isolated natural communities in running waters. Pages 111-119 in R. A. Vollenweider (editor). A manual on methods for measuring primary production in aquatic environments. Blackwell Scientific Publications, Oxford, UK.

PAsconl, C., F. CAssio, AND P. Gomes. 2001. Leaf breakdown rates: a measure of water quality? International Review of Hydrobiology 86:407-416.

Pascoal, C., M. Pinho, F. Cassio, and P. Gomes. 2003. Assessing structural and functional ecosystem condition using leaf breakdown: studies on a polluted river. Freshwater Biology 48:2033-2044.

Paul, M. J., And J. L. Meyer. 2001. Streams in the urban landscape. Annual Reviews in Ecology and Systematics 32:333-365.

Paul, M. J., J. L. Meyer, And C. A. Couch. 2006. Leaf breakdown in streams differing in catchment land use. Freshwater Biology 51:1684-1695.

Peterson, C. G. 1996. Response of benthic algal communities to natural physical disturbance. Pages 375-402 in R. J. Stevenson, M. L. Bothwell, and R. L. Lowe (editors). Algal ecology: freshwater benthic ecosystems. Academic Press, San Diego, California.

Petersen, R. C., And K. W. Cummins. 1974. Leaf processing in a woodland stream. Freshwater Biology 4:343-368.

Phinney, H. K., AND C. D. McIntire. 1965. Effect of temperature on metabolism of periphyton communities developed in laboratory streams. Limnology and Oceanography 10:341-344.

Pozo, J. 1993. Leaf litter processing of alder and eucalyptus in 
the Aguera stream system (North Spain). I. Chemical changes. Archiv für Hydrobiologie 127:299-317.

Pozo, J., A. Basaguren, A. Elosegui, J. Molinero, E. Fabre, and E. Chauvet. 1998. Afforestation with Eucalyptus globulus and leaf litter decomposition in streams of northern Spain. Hydrobiologia 373-374:101-109.

QuinN, J. M., G. P. Burrell, AND S. M. Parkyn. 2000. Influences of leaf toughness and nitrogen content on in-stream processing and nutrient uptake by litter in a Waikato, New Zealand, pasture stream and streamside channels. New Zealand Journal of Marine and Freshwater Research 34:253-271.

QuinN, J. M., And P. N. McFarlane. 1989. Epilithon and dissolved oxygen depletion in the Manawatu River, New Zealand: simple models and management implications. Water Research 23:825-832.

QuinN, J. M., N. R. Phillips, AND S. M. PARKYN. 2007. Factors influencing retention of coarse particulate organic matter in streams. Earth Surface Processes and Landforms 32: 1186-1203.

Rader, R. B., J V. McArthur, And J. M. Aho. 1994. Relative importance of mechanisms determining decomposition in a southeastern blackwater stream. American Midland Naturalist 132:19-31.

Rama RaO, S. V., V. P. Singh, And L. P. Mall. 1979. The effect of sewage and industrial waste discharges on the primary production of a shallow turbulent river. Water Research 13:1017-1021.

Raviraja, N. S., K. R. SRIDHAR, AND F. BÄrLOCher. 1998. Breakdown of Ficus and Eucalyptus leaves in an organically polluted river in India: fungal diversity and ecological functions. Freshwater Biology 39:537-545.

ReICE, S. R. 1974. Environmental patchiness and the breakdown of leaf litter in a woodland stream. Ecology 55:1271-1282.

RiER, S. T., AND D. K. KING. 1996. Effects of inorganic sedimentation and riparian clearing on benthic community metabolism in an agriculturally-disturbed stream. Hydrobiologia 339:111-121.

Riipinen, M. P., J. Davy-Bowker, And M. Dobson. 2008. Comparison of structural and functional stream assessment methods to detect changes in riparian vegetation and water $\mathrm{pH}$. Freshwater Biology (in press). doi:10. 1111/j.1365-2427.2008.01964.x.

Robinson, C. T., AND M. O. Gessner. 2000. Nutrient addition accelerates leaf breakdown in an alpine springbrook. Oecologia (Berlin) 122:258-263.

Robinson, C. T., M. O. Gessner, And J. V. WARD. 1998. Leaf breakdown and associated macroinvertebrates in alpine glacial streams. Freshwater Biology 40:215-228.

Rosemond, A. D., C. M. PRingle, AND A. RAmirez. 1998. Macroconsumer effects on insect detritivores and detritus processing in a tropical stream. Freshwater Biology 39:515-523.

Rosemond, A. D., C. M. Pringle, A. Ramirez, M. J. Paul, And J. L. MeYer. 2002. Landscape variation in phosphorus concentration and effects on detritus-based tropical streams. Limnology and Oceanography 47:278-289.

Rosenfeld, J. S., AND J. C. Roff. 1991. Primary production and potential availability of autochthonous carbon in southern Ontario streams. Hydrobiologia 224:99-109.

Rosset, J., F. BÄrlocher, AND J. J. OertLI. 1982. Decomposition of conifer needles and deciduous leaves in two Black Forest and two Swiss Jura streams. Internationale Revue der gesamten Hydrobiologie 67:695-711.

RounicK, J. S., AND M. J. Winterbourn. 1983. Leaf processing in two contrasting beech forest streams: effects of physical and biotic factors on litter breakdown. Archiv für Hydrobiologie 94:448-474.

Rowe, J. M., S. K. Meegan, E. S. Engstrom, S. A. Perry, and W. B. Perry. 1996. Comparison of leaf processing rates under different temperature regimes in three headwater streams. Freshwater Biology 36:277-288.

Royer, T. V., AND G. W. Minshall. 2001. Effects of nutrient enrichment and leaf quality on the breakdown of leaves in a hardwater stream. Freshwater Biology 46:603-610.

Sabater, F., A. Butturini, I. Muñoz, A. Romaní, S. Sabater, E. MARTí, AND J. WRAY. 2000. Effects of riparian vegetation removal on nutrient retention in a Mediterranean stream. Journal of the North American Benthological Society 19: 609-620.

SAMPAIO, A., R. CORTES, AND C. LeaO. 2001. Invertebrate and microbial colonisation in native and exotic leaf litter species in a mountain stream. International Review of Hydrobiology 86:527-540.

Schofield, K. A., C. M. Pringle, J. L. Meyer, And A. B. SutHERLAND. 2001. The importance of crayfish in the breakdown of rhododendron leaf litter. Freshwater Biology 46:1191-1204.

Schultheis, A. S., AND A. C. Hendricks. 1999. The role of copper accumulations on leaves in the inhibition of leaf decomposition in a mountain stream. Journal of Freshwater Ecology 14:31-40.

SHORT, R. A., AND S. L. SMItH. 1989. Seasonal comparison of leaf processing in a Texas stream. American Midland Naturalist 12:219-224.

SHORT, R. A., AND J. V. WARD. 1980. Leaf litter processing in a regulated Rocky Mountain stream. Canadian Journal of Fisheries and Aquatic Sciences 37:123-127.

Siefert, J., AND M. Mutz. 2001. Processing of leaf litter in acid waters of the post-mining landscape in Lusatia, Germany. Ecological Engineering 17:297-306.

Simonsen, J. F., and P. Harremoes. 1978. Oxygen and $\mathrm{pH}$ fluctuations in rivers. Water Research 12:477-489.

SinSABAUgH, R. L. 1997. Large-scale trends for stream benthic respiration. Pages 119-122 in J. R. Webster and J. L. Meyer (editors). Stream organic matter budgets. Journal of the North American Benthological Society 16:3-161.

SMitH, D. L. 1986. Leaf litter processing and the associated invertebrate fauna in a tallgrass prairie stream. American Midland Naturalist 116:78-86.

Speaker, R., K. Moore, and S. Gregory. 1984. Analysis of the process of retention of organic matter in stream ecosystems. Verhandlungen der Internationalen Vereinigung für theoretische und angewandte Limnologie 22: 1835-1841.

Sridhar, K. R., G. Krauss, F. Bärlocher, N. S. Raviraja, R. Wennrich, R. Baumbach, and G. J. Krauss. 2001. 
Decomposition of alder leaves in two heavy metalpolluted streams in central Germany. Aquatic Microbial Ecology 26:73-80.

Stewart, B. A., AND B. R. DAvies. 1989. The influence of different litter bag designs on the breakdown of leaf material in a small mountain stream. Hydrobiologia 183: 173-177.

Suberkropp, K., AND E. Chauvet. 1995. Regulation of leaf breakdown by fungi in streams: influences of water chemistry. Ecology 76:1433-1445.

Suberkropr, K. F., G. L. Godshalk, and M. J. Klug. 1976. Changes in the chemical composition of leaves during processing in a woodland stream. Ecology 57:720-727.

SubERKROPP, K., AND M. J. KLUG. 1980. The maceration of deciduous leaf litter by aquatic hyphomycetes. Canadian Journal of Botany 58:1025-1031.

TANK, J. L., AND M. J. WinterbouRN. 1996. Microbial activity and invertebrate colonisation of wood in a New Zealand forest stream. New Zealand Journal of Marine and Freshwater Research 30:271-280.

Tiegs, S. D., S. D. Langhans, K. Tockner, and M. O. Gessner. 2007. Cotton strips as a leaf surrogate to measure decomposition in river floodplain habitats. Journal of the North American Benthological Society 26:70-77.

TRISKA, F. J., AND B. M. BuCKLEY. 1978. Patterns of nitrogen uptake and loss in relation to litter disappearance and associated invertebrate biomass in six streams of the Pacific Northwest, U.S.A. Verhandlungen der Internationalen Vereinigung für theoretische und angewandte Limnologie 20:1324-1332.

UeHLinger, U. 2000. Resistance and resilience of ecosystem metabolism in a flood-prone river system. Freshwater Biology 45:319-332.

UEHLINGER, U. 2006. Annual cycle and inter-annual variability of gross primary production and ecosystem respiration in a floodprone river during a 15-year period. Freshwater Biology 51:938-950.

UeHLinger, U., B. KAWECKA, AND C. T. Robinson. 2003. Effects of experimental floods on periphyton and stream metabolism below a high dam in the Swiss Alps (River Spol). Aquatic Science 65:199-209.

UeHLinger, U., AND M. W. NAEgeli. 1998. Ecosystem metabolism, disturbance, and stability in a prealpine gravel bed river. Journal of the North American Benthological Society 17:165-178.

Usio, N. 2000. Effects of crayfish on leaf processing and invertebrate colonisation of leaves in a headwater stream: decoupling of a trophic cascade. Oecologia (Berlin) 124:608-614.

Uzarski, D. G., T. M. Burton, and C. A. Stricker. 2001. A new chamber design for measuring community metabolism in a Michigan stream. Hydrobiologia 455:137-155.

Vannote, R. L., G. W. Minshall, K. W. Cummins, J. R. Sedell, AND C. E. Cushing. 1980. The river continuum concept. Canadian Journal of Fisheries and Aquatic Sciences 37: 130-137.

Wallace, J. B., J. W. Grubaugh, and M. R. Whiles. 1996. Biotic indices and stream ecosystem processes: results from an experimental study. Ecological Applications 6:140-151.
Wallace, J. B., J. R. Webster, and T. F. Cuffney. 1982. Stream detritus dynamics: regulation by invertebrate consumers. Oecologia (Berlin) 53:197-200.

Webster, J. R., and E. F. Benfield. 1986. Vascular plant breakdown in freshwater ecosystems. Annual Review of Ecology and Systematics 17:567-594.

Webster, J. R., AND J. L. Meyer. 1997. Stream organic matter budgets. Journal of the North American Benthological Society 16:3-161.

Webster, J. R., AND J. B. WAide. 1982. Effects of forest clearcutting on leaf breakdown in a southern Appalachian stream. Freshwater Biology 12:331-344.

Webster, J. R., J. B. Wallace, and E. F. Benfield. 1995. Organic processes in streams of the eastern United States. Pages 117-187 in C. E. Cushing, K. W. Cummins, and G. W. Minshall (editors). River and stream ecosystems. Elsevier Science, Amsterdam, Netherlands.

Whiles, M. R., and J. B. Wallace. 1997. Leaf litter decomposition and macroinvertebrate communities in headwater streams draining pine and hardwood catchments. Hydrobiologia 353:107-119.

Wilcock, R. J. 1982. Simple predictive equations for calculating stream reaeration rate coefficients. New Zealand Journal of Science 25:53-56.

Wilcock, R. J., G. B. McBride, J. W. Nagels, and G. L. Northсотт. 1995. Water quality in a polluted lowland stream with chronically depressed dissolved oxygen: causes and effects. New Zealand Journal of Marine and Freshwater Research 29:277-288.

Wilcock, R. J., J. W. Nagels, G. B. McBride, K. J. Collier, B. T. Wilson, AND B. A. Huser. 1998. Characterisation of lowland streams using a single-station diurnal curve analysis model with continuous monitoring data for dissolved oxygen and temperature. New Zealand Journal of Marine and Freshwater Research 32:67-79.

Wilcock, R. J., J. W. Nagels, M. B. O'Connor, B. S. Thorrold, AND J. W. BARNETT. 1999. Water quality of a lowland stream in a New Zealand dairy farming catchment. New Zealand Journal of Marine and Freshwater Research 33: 683-696.

Wiley, M. J., L. L. Osbourne, and R. W. Larimore. 1990. Longitudinal structure of an agricultural prairie river system and its relationship to current stream ecosystem theory. Canadian Journal of Fisheries and Aquatic Sciences 47:373-384.

YounG, R. G. 1998. Patterns of ecosystem metabolism and organic matter transport in rivers. PhD Thesis, University of Otago, Dunedin, New Zealand.

YounG, R. G., AND A. D. HuRYN. 1996. Interannual variation in discharge controls ecosystem metabolism along a grassland river continuum. Canadian Journal of Fisheries and Aquatic Sciences 53:2199-2211.

YounG, R. G., And A. D. Huryn. 1998. Comment: Improvements to the diurnal upstream-downstream dissolved oxygen change technique for determining whole-stream metabolism in small streams. Canadian Journal of Fisheries and Aquatic Sciences 55:1784-1785.

YounG, R. G., AND A. D. Huryn. 1999. Effects of land use on 
stream metabolism and organic matter turnover. Ecological Applications 9:1359-1376.

Young, R. G., A. D. Huryn, And C. R. Townsend. 1994. Effects of agricultural development on processing of tussock leaf litter in high country New Zealand streams. Freshwater Biology 32:413-427.

Received: 20 September 2007 Accepted: 15 May 2008 